\title{
Sensitivity of remote aerosol distributions to representation of cloud-aerosol interactions in a global climate model
}

\author{
H. Wang, R. C. Easter, P. J. Rasch, M. Wang, X. Liu, S. J. Ghan, Y. Qian, J.-H. Yoon, P.-L. Ma, and V. Vinoj \\ Atmospheric Sciences and Global Change Division, Pacific Northwest National Laboratory (PNNL), Richland, \\ Washington, USA
}

Correspondence to: H. Wang (hailong.wang@ pnnl.gov)

Received: 4 December 2012 - Published in Geosci. Model Dev. Discuss.: 21 January 2013

Revised: 9 April 2013 - Accepted: 3 May 2013 - Published: 5 June 2013

\begin{abstract}
Many global aerosol and climate models, including the widely used Community Atmosphere Model version 5 (CAM5), have large biases in predicting aerosols in remote regions such as the upper troposphere and high latitudes. In this study, we conduct CAM5 sensitivity simulations to understand the role of key processes associated with aerosol transformation and wet removal affecting the vertical and horizontal long-range transport of aerosols to the remote regions. Improvements are made to processes that are currently not well represented in CAM5, which are guided by surface and aircraft measurements together with results from a multi-scale aerosol-climate model that explicitly represents convection and aerosol-cloud interactions at cloud-resolving scales. We pay particular attention to black carbon (BC) due to its importance in the Earth system and the availability of measurements.

We introduce into CAM5 a new unified scheme for convective transport and aerosol wet removal with explicit aerosol activation above convective cloud base. This new implementation reduces the excessive $\mathrm{BC}$ aloft to better simulate observed $\mathrm{BC}$ profiles that show decreasing mixing ratios in the mid- to upper-troposphere. After implementing this new unified convective scheme, we examine wet removal of submicron aerosols that occurs primarily through cloud processes. The wet removal depends strongly on the subgrid-scale liquid cloud fraction and the rate of conversion of liquid water to precipitation. These processes lead to very strong wet removal of $\mathrm{BC}$ and other aerosols over mid- to high latitudes during winter months. With our improvements, the Arctic BC burden has a 10-fold (5-fold) increase in the winter (summer) months, resulting in a muchbetter simulation of the $\mathrm{BC}$ seasonal cycle as well. Arctic
\end{abstract}

sulphate and other aerosol species also increase but to a lesser extent. An explicit treatment of BC aging with slower aging assumptions produces an additional 30-fold (5-fold) increase in the Arctic winter (summer) BC burden. This BC aging treatment, however, has minimal effect on other underpredicted species. Interestingly, our modifications to CAM5 that aim at improving prediction of high-latitude and uppertropospheric aerosols also produce much-better aerosol optical depth (AOD) over various other regions globally when compared to multi-year AERONET retrievals. The improved aerosol distributions have impacts on other aspects of CAM5, improving the simulation of global mean liquid water path and cloud forcing.

\section{Introduction}

As one of the most uncertain forcing agents in the Earth's climate system, aerosols and their representation in climate models continue to be a challenge for climate research. The Community Earth System Model (CESM) is widely used for climate change research. The atmospheric component of the CESM, the Community Atmosphere Model version 5 (CAM5; Neale et al., 2010), includes relatively comprehensive representations of aerosols and mechanisms for interactions with clouds and climate (Gettelman et al., 2008; Liu et al., 2012; Ghan et al., 2012). Like many other global aerosol and climate models (Kinne et al., 2006; Koch et al., 2009b; Qian et al., 2012), CAM5 produces a relatively poor simulation of aerosols and clouds in remote regions (upper troposphere and high latitudes) compared to those in other regions. CAM5 strongly underestimates Arctic aerosol surface 
concentrations, particularly during the Arctic haze season (winter to early spring), and overpredicts upper-tropospheric aerosols in lower latitudes (Wang et al., 2011b; Liu et al., 2012). In this study we use sensitivity tests to explore the reasons for these biases in the CAM5 model, but we believe the underlying issues and solutions are also likely to be relevant to other global models. We describe changes designed to reduce the biases, interpret those changes in the context of the basic physics of aerosol-cloud interactions, and demonstrate the improvements to the CAM5 simulation of aerosols in remote regions and changes to global aerosol distributions.

Aerosols are important in the Earth system. They affect the Earth's energy budget directly by scattering and absorbing shortwave and longwave radiation, and also affect cloud and warm-rain processes that further influence the surface and atmospheric radiation balance (e.g., Twomey, 1974; Albrecht, 1989; Boucher, 1995; Rosenfeld, 2000; Wang and Feingold, 2009; Feingold et al., 2010). Aerosols in the upper troposphere and cold, remote regions (e.g., high-latitude regions) are also likely to affect ice clouds and precipitation (e.g., Fridlind et al., 2004; Morrison et al., 2012). The vertical distribution of absorbing aerosols such as black carbon (BC) is particularly important due to their effect on the atmospheric heating profile and resultant change in thermodynamic structure and cloud amount (i.e., "semi-direct effect"). This effect depends on the location of absorbing aerosols in relation to the cloud layer (e.g., McFarquhar and Wang, 2006; Koch and Del Genio, 2010). Absorbing aerosols deposited onto snow and ice surface can enhance absorption of shortwave radiation at the surface, resulting in a warming of the lower atmosphere and more-rapid melting of snow and ice (Warren and Wiscombe, 1980; Flanner et al., 2007; Doherty et al., 2010; Qian et al., 2011; Wang et al., 2011). Therefore, global three-dimensional aerosol distributions, particularly over remote regions away from sources (e.g., the Arctic and upper troposphere), are important in the Earth's climate system.

Arctic aerosols largely originate from lower latitudes, despite some local seasonal natural and anthropogenic sources (e.g., Law and Stohl, 2007; Quinn et al., 2007). The observed distinct seasonal cycle with a minimum in summer and maximum in late winter and early spring (Sharma et al., 2006) is closely related to transport from source regions outside the Arctic. Aerosol dry/wet removal at lower latitudes can strongly influence the distribution of aerosols at high latitudes (e.g., Kinne et al., 2006; Textor et al., 2007; Shindell et al., 2008; Bourgeois and Bey, 2011; Browse et al., 2012). Wet removal is considered to be the dominant process that determines the amount of aerosols being transported to remote regions and is also one of the most uncertain processes in global aerosol-climate models (Textor et al., 2006). Wet removal by liquid-cloud scavenging and precipitation is of particular importance. Garrett et al. (2011) and Browse et al. (2012) showed that the seasonal cycle of Arctic BC is primarily driven by temperature-dependent wet scavenging processes during transport from source regions to the Arctic and/or within the Arctic. Unfortunately, climate models have historically tended to overestimate low clouds in the Arctic region, particularly wintertime low-level liquid clouds (e.g., Vavrus and Waliser, 2008; Qian et al., 2012).

The vertical distribution of aerosols in the free troposphere depends strongly on convective transport and wet removal by convective clouds. Koch et al. (2009b) showed that the AeroCom models generally overestimate $\mathrm{BC}$ in the mid- to uppertroposphere at low to mid-latitudes, and they found that increasing wet removal by convective clouds can reduce the bias. In the standard CAM5, convective transport and wet removal of aerosols are treated separately (although weakly coupled), without secondary activation of aerosols entrained into updrafts. This might explain why simulated BC in the upper troposphere is too high (Liu et al., 2012).

Regarding aerosol wet removal during the transport to remote regions, modeling studies have shown that chemical and physical transformations (i.e., aging processes that transform particles from a mostly hydrophobic state upon emission to a more hydrophilic state) can be also very important (e.g., Vignati et al., 2010; Liu et al., 2011a). Condensation of soluble material (e.g., sulfuric acid gas and condensable organics), coagulation with soluble particles and oxidation of organic material can be involved in aging, but uncertainties remain (Pöschl et al., 2001; Riemer et al., 2004). When BC aging is represented in global models, it is either simply parameterized by prescribing a fixed aging timescale (e.g., Collins et al., 2001) or represented more explicitly by treating condensation/coagulation with some simplifications (e.g., Vignati et al., 2004; Liu et al., 2012) because it is computationally impractical to explicitly treat the most detailed representations of the aging process (Riemer et al., 2009; Zaveri et al., 2010) in global models.

Koch et al. (2009b) compared global BC predictions from 17 AeroCom models, including an older version of CAM, and evaluated model results against surface and aircraft measurements. Their study revealed large discrepancies and diversities, with some of the largest occurring in northern Eurasia and the remote Arctic. CAM5 suffers from some of the same biases. Wang et al. (2011b) showed that the standard CAM5 underpredicted BC concentrations by up to two orders of magnitude at several polar sites and did not capture the observed seasonal cycle. In contrast, they found that the observed BC concentrations were better predicted by another CAM5 variant called the Pacific Northwest National Laboratory Multi-scale Modeling Framework (PNNL-MMF) aerosol-climate model, which embeds a cloud-resolving model in each CAM5 grid column to explicitly represent aerosol-cloud interactions in both convective and stratiform clouds.

The objectives of this study are to elucidate roles and improve treatments of processes associated with aerosol transformation, wet scavenging, convective transport and removal that are key to determining the amount of aerosols reaching remote regions. We conduct sensitivity simulations to 
understand the role of each of the processes and to identify sources of uncertainties in the model. The CAM5 simulations with our modifications are evaluated using surface and aircraft measurements of aerosol properties and processoriented model results (including aerosol and cloud properties) from the PNNL-MMF model. Based on the evaluations, improvements are made to aerosol-cloud processes that are currently not well represented in CAM5, to produce a better aerosol simulation.

\section{Model description, methods and simulations}

\subsection{Model descriptions}

\subsubsection{CAM5}

We use a developmental version (5.0.40) of the CAM5 (Neale et al., 2010), which has nearly identical physics to the released version CAM5.1. Aerosol evolution in CAM5 is controlled by a combination of emission, transport (by resolved winds, turbulence, convective clouds, and sedimentation), aerosol microphysics (condensation, coagulation, and new particle formation), cloud chemistry, and wet and dry removal. Here we briefly summarize aspects that are important for remote region aerosols. The Supplement (Sect. S2) provides more information and Liu et al. (2012) provides a detailed description of the aerosol treatment and evaluation results.

CAM5 uses a modal aerosol module (MAM) where the aerosol size distribution is described by a set of lognormally distributed modes with prescribed geometric standard deviations $\left(\sigma_{\mathrm{g}}\right)$ and predicted mode diameters. The standard version (MAM3) uses three modes: Aitken $\left(\sigma_{\mathrm{g}}=1.6\right.$; dry diameter size range: $15-53 \mathrm{~nm})^{1}$, accumulation $\left(\sigma_{\mathrm{g}}=1.8 ; 58-\right.$ $270 \mathrm{~nm})$, and a single coarse mode $\left(\sigma_{\mathrm{g}}=1.8 ; 0.80-3.85 \mu \mathrm{m}\right)$. There is also a more detailed seven-mode version (MAM7) with Aitken $\left(\sigma_{\mathrm{g}}=1.8 ; 15-52 \mathrm{~nm}\right)$, accumulation $\left(\sigma_{\mathrm{g}}=1.8\right.$; $56-260 \mathrm{~nm})$, primary carbon $\left(\sigma_{\mathrm{g}}=1.6 ; 39-130 \mathrm{~nm}\right)$, fine sea salt $\left(\sigma_{\mathrm{g}}=2.0 ; 95-560 \mathrm{~nm}\right)$, fine dust $\left(\sigma_{\mathrm{g}}=1.8 ; 140\right.$ $620 \mathrm{~nm})$, coarse sea salt $\left(\sigma_{\mathrm{g}}=2.0 ; 0.63-3.70 \mu \mathrm{m}\right)$ and coarse dust modes $\left(\sigma_{\mathrm{g}}=1.8 ; 0.59-2.75 \mu \mathrm{m}\right)$. Modes are composed of sulphate, $\mathrm{BC}$, primary organic matter (POM), secondary organic aerosol (SOA), sea salt, mineral dust, and water, although all the species are not present in every mode. The primary carbonaceous aerosol emissions (BC, $\mathrm{POM}$ ) have a $\sigma_{\mathrm{g}}=1.8$ and number mode diameter of $80 \mathrm{~nm}$. Dust and sea salt are emitted at different size ranges for MAM3 and MAM7 as described in Liu et al. (2012). Within each mode, internal mixing of species in particles is assumed. BC and POM are emitted into the accumulation mode in MAM3. They are assumed to immediately mix with any hygroscopic

\footnotetext{
${ }^{1}$ Size ranges for particle diameters are the 10th and 90th percentiles of the global annual average number size distribution for the modes (Liu et al., 2012).
}

species (sulphate, SOA, sea salt) in this mode and become susceptible to wet scavenging. In contrast, BC and POM are emitted into the primary carbon mode in MAM7, and then are gradually and directly transferred to the accumulation mode as they age by condensation of soluble material and coagulation with other soluble particles. Although the BC and POM particles have the same size distribution upon emission in MAM3 and MAM7, in the MAM7 primary carbon mode they have low hygroscopicity (compared to accumulation mode) and are less susceptible to activation and wet removal. Biomass burning and anthropogenic components of $\mathrm{BC}$ and POM are not separated in the modal aerosol module configurations used in this study, but they have been separated in some other MAM studies (e.g., Ghan et al., 2012).

CAM5 has separate parameterizations of stratiform and convective clouds, and aerosol wet removal occurs for both types of clouds by in-cloud and below-cloud processes. For submicron particles (which include nearly all sulphate and all BC, POM, and SOA in CAM5), the predominant removal mechanism is in-cloud wet removal. This involves aerosol activation to form cloud droplets, followed by conversion of cloud droplets to precipitation. For stratiform clouds, cloudborne (i.e., activated) particles are treated explicitly, and activation is calculated with the parameterization of AbdulRazzak and Ghan (2000). Stratiform in-cloud wet removal is affected by the liquid-containing cloud fraction/frequency, the fraction of particles that are activated, and the rate at which cloud droplets (and cloud-borne particles) are removed.

Convective clouds affect aerosols both by vertical transport and wet removal. Although these two processes occur together in nature, the standard CAM5 has separate (although weakly coupled) treatments of them. Aerosol activation prior to wet removal is treated in a simpler manner than in stratiform clouds. Also, there is no mechanism for laterally entrained aerosols to be activated/scavenged, allowing the transport of more aerosols to the upper troposphere. A new unified treatment of these aerosol processes in convective clouds, which better treats aerosol wet removal in updrafts (see Supplement Sect. S1), is applied in this study. It has a more detailed treatment of aerosol activation in updrafts, both at and above cloud base.

\subsubsection{PNNL-MMF}

The PNNL-MMF (hereafter, MMF) is a general circulation model (GCM) that embeds a 2-D cloud-resolving model (CRM) in each of its global-scale grid columns to explicitly represent clouds (including aerosol effects), both convective and stratiform (Wang et al., 2011a). Each CRM has 32 vertical columns with $4 \mathrm{~km}$ horizontal resolution. The GCM component of the MMF is adapted from CAM5, so the MMF and CAM5 have much commonality, including dynamical core, radiation parameterizations, and the modal aerosol treatment. Primary differences from CAM5 in the treatment of clouds 
are that the CRM treats all types of clouds with detailed microphysics and aerosol indirect effects (without convective parameterization), there are no empirical parameterizations of cloud fractional area (cloud macrophysics), and there are prognostic rather than diagnostic treatments of precipitation in the microphysics. Primary differences in the treatment of aerosols are that cloud parameters (e.g., cloud fraction, liquid water, cloud-water removal rates, updraft and downdraft mass fluxes) that influence aerosol wet removal, vertical transport, and cloud chemistry are taken from the CRM calculations (averaged over a GCM time step and grid cell) rather than from conventional cloud parameterizations. Treatments of aerosol emissions, microphysics, and dry deposition are identical.

\subsection{Motivation for model changes to CAM5}

The two models (MMF and CAM5) have many common features (particularly involving aerosols), but the MMF gives a better simulation of several aspects of aerosol fields, particularly at the remote high latitudes in wintertime (Wang et al., 2011b), so comparison of results from the two models may suggest how the CAM5 simulation can be improved. We recognize of course that this is less desirable than improving model components through direct use of observations; however, the model intercomparison can use diagnostic quantities that affect aerosol wet removal processes (and thus transport to remote regions) but are not generally available from observations. For the moment, we focus on evaluating the representation of these processes that contribute to differences in winter season BC between the MMF and CAM5, to exploit potential deficiencies in CAM5 parameterizations and to inform design of model sensitivity tests.

The standard CAM5 simulation (denoted as CAM5std in Table 1, which also describes other CAM5 simulations used in this study) is conducted at $1.9^{\circ} \times 2.5^{\circ}$ horizontal resolution with 30 hybrid vertical levels for $11 \mathrm{yr}$, and the last 10 are used for analysis. The computationally expensive MMF, which is about 200 times more costly per year of simulation, was run for $4 \mathrm{yr}$ (last 3 used in the analysis), using the same resolution. Both CAM5std and MMF are run with prescribed sea surface temperature (year 2000 with seasonal but no year-to-year variability), three aerosol modes (MAM3), and aerosol and trace gas emissions for the year 2000 as described in Liu et al. (2012).

Figure 1 shows the DJF zonal-mean values of several quantities relevant to $\mathrm{BC}$ burden and wet removal from the MMF and the standard CAM5 simulations. These include the $\mathrm{BC}$ total column burden $\left(B\right.$, in $\left.\mu \mathrm{g} \mathrm{m}^{-2}\right)$, the $\mathrm{BC}$ surfacelayer mixing ratio, the $\mathrm{BC}$ surface wet-deposition flux $\left(F_{\mathrm{w}}\right.$, in $\mu \mathrm{g} \mathrm{m}^{-2}$ day $^{-1}$, which is equivalent to the column-integrated wet removal), and the $\mathrm{BC}$ first-order wet-removal rate $\left(R_{\mathrm{w}}\right.$, in day ${ }^{-1}$ ), defined as

$R_{\mathrm{w}}=F_{\mathrm{w}} / B$.
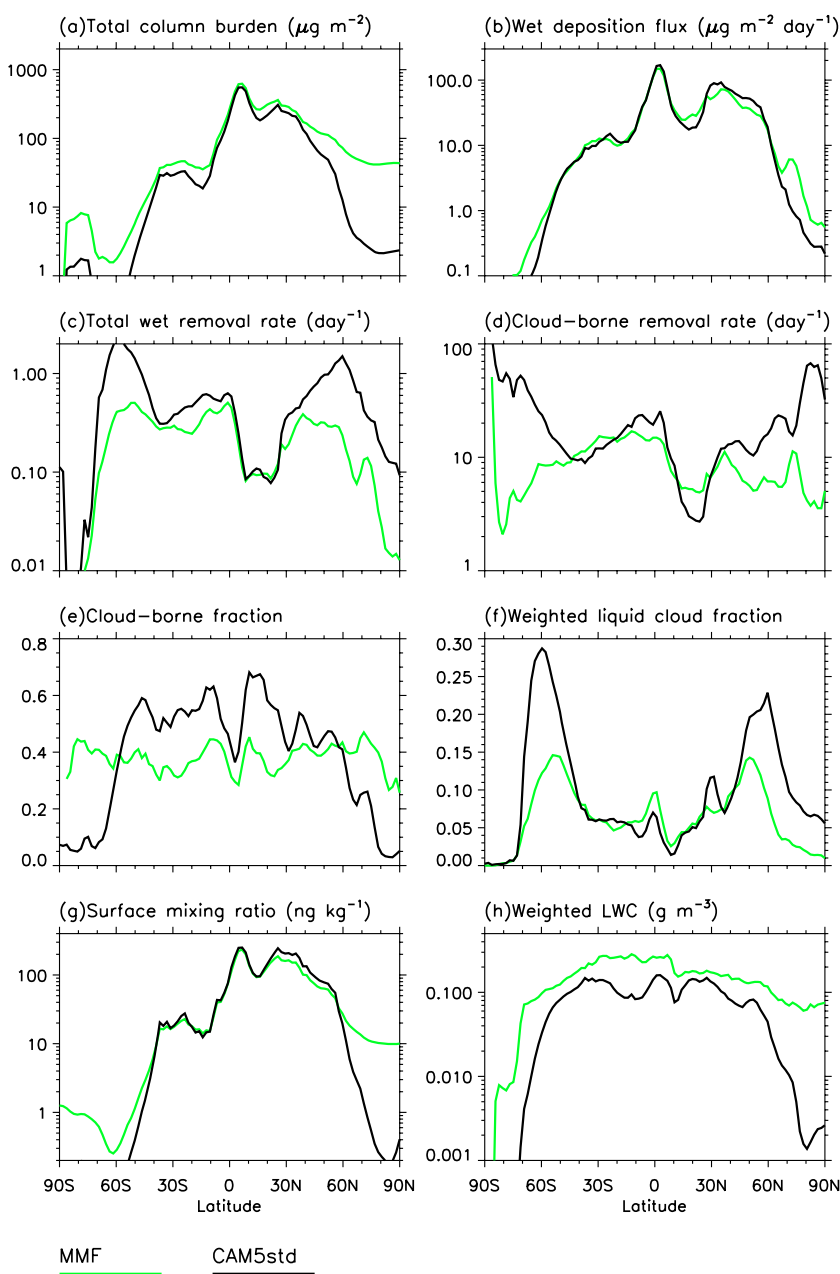

MMF

Fig. 1. DJF zonal-mean values of the quantities related to BC burden and removal, as described in Eqs. (1)-(3), derived from the MMF and the standard CAM5 simulations. The column burden is the vertical integral from the surface to $650 \mathrm{hPa}$.

We use the total BC (i.e., both interstitial and cloudborne) in these quantities, because wet removal includes both in-cloud (activation of interstitial BC followed by wet removal of the cloud-borne $\mathrm{BC}$ ) and below-cloud (impaction and Brownian-diffusion scavenging of interstitial $\mathrm{BC}$ ) processes. $B$ is obtained from monthly average mixing ratios at each model grid point, which are integrated vertically and then further averaged over multiple simulation months (e.g., DJF) and years. $F_{\mathrm{w}}$ is obtained from monthly average wetdeposition fluxes for each vertical column, and then further averaged in the same way as for $B$. (Note, however, that wet removal and precipitation-borne aerosol sedimentation fluxes are calculated at each level in the model.) $R_{\mathrm{w}}$, which is derived from the averaged $B$ and $F_{\mathrm{w}}$ values using Eq. (1), represents the inverse timescale for wet removal of the column BC burden. Note that it could be calculated at each model level and time step, and then averaged; this would give somewhat different numerical results. 
Table 1. Summary of sensitivity simulations and modifications made to the standard CAM5.

\begin{tabular}{|c|c|c|c|c|c|c|}
\hline $\begin{array}{l}\text { Change } \\
\text { made } \\
\text { in } \\
\text { simulations }\end{array}$ & $\begin{array}{l}\text { Inconsistency } \\
\text { involving } \\
\text { subgrid } \\
\text { liquid cloud } \\
\text { fractions } \\
\text { eliminated }\end{array}$ & $\begin{array}{c}\text { New treatment } \\
\text { of } \\
\text { convective } \\
\text { transport and } \\
\text { wet removal } \\
\text { of aerosols }\end{array}$ & $\begin{array}{c}\text { Secondary } \\
\text { aerosol } \\
\text { activation } \\
\text { above cloud } \\
\text { base in new } \\
\text { convection scheme }\end{array}$ & $\begin{array}{l}\text { Freeze-dry } \\
\text { scheme } \\
\text { reduces } \\
\text { liquid } \\
\text { cloud } \\
\text { fraction }\end{array}$ & $\begin{array}{l}\text { Lower stratiform } \\
\text { stratiform } \\
\text { in-cloud } \\
\text { wet-removal } \\
\text { adjustment } \\
\text { factor }\end{array}$ & $\begin{array}{c}\text { MAM7 with } \\
\text { slower } \\
\text { BC } \\
\text { aging } \\
\text { (instead } \\
\text { of MAM3) }\end{array}$ \\
\hline \multicolumn{7}{|l|}{ CAM5std } \\
\hline CTRL & $\mathrm{x}$ & & & & & \\
\hline CONV & $\mathrm{x}$ & $\mathrm{x}$ & & & & \\
\hline CONV_sact & $\mathrm{x}$ & $\mathrm{x}$ & $\mathrm{x}$ & & & \\
\hline CONV_FD & $\mathrm{x}$ & $\mathrm{x}$ & & $\mathrm{x}$ & & \\
\hline CONV_SF & $\mathrm{x}$ & $\mathrm{x}$ & & & $\mathrm{x}$ & \\
\hline CONV_m7 & $\mathrm{x}$ & $\mathrm{x}$ & & & & $\mathrm{x}$ \\
\hline ALL_m3 & $\mathrm{x}$ & $\mathrm{x}$ & $\mathrm{x}$ & $\mathrm{x}$ & $\mathrm{x}$ & \\
\hline ALL_m7 & $\mathrm{x}$ & $\mathrm{x}$ & $\mathrm{x}$ & $\mathrm{x}$ & $\mathrm{x}$ & $\mathrm{x}$ \\
\hline
\end{tabular}

The two models have substantial differences in all quantities that are generally strongest at high latitudes but begin at mid-latitudes. The ratio of total $\mathrm{BC}$ burdens between the two runs is close to 0.8 from the Equator to $35^{\circ} \mathrm{N}$, which suggests that model differences at these latitudes do not contribute significantly to the much-stronger differences at high latitudes. The burden difference increases gradually from $35^{\circ} \mathrm{N}$ to about $55^{\circ} \mathrm{N}$, and then rapidly to about $65^{\circ} \mathrm{N}$. In the $35^{\circ}-65^{\circ} \mathrm{N}$ latitude range, the $\mathrm{BC}$ wet-deposition flux $\left(F_{\mathrm{w}}\right)$ is slightly higher in CAM5std, and the first-order total-aerosol wet-removal rate $\left(R_{\mathrm{w}}\right)$ is almost 10 times higher. Thus the $\mathrm{BC}$ wet removal in CAM5std is much more efficient in this mid-latitude range. Interestingly, the near-surface $\mathrm{BC}$ mixing ratio is higher in CAM5std than MMF in mid-latitudes $\left(30^{\circ}-\right.$ $60^{\circ} \mathrm{N}$ ), which can be attributed in part to stronger aerosol resuspension from evaporating precipitation in CAM5 than in the MMF (figure not shown). Between $65^{\circ}-90^{\circ} \mathrm{N}$, the total-BC burden in CAM5std drops more gradually than in the mid-latitude range, but the surface mixing ratio declines rapidly until about $80^{\circ} \mathrm{N}$.

The other quantities shown in Fig. 1 are obtained by decomposing the wet-removal rate into three terms:

$R_{\mathrm{w}}=\left(F_{\mathrm{w}} / B_{\mathrm{c}}\right) \cdot\left(B_{\mathrm{c}} /\left\langle f_{\mathrm{ct}}\right\rangle B\right) \cdot\left(\left\langle f_{\mathrm{ct}}\right\rangle\right)$.

Here $B_{\mathrm{c}}$ is the column burden of cloud-borne $\mathrm{BC}$, and $\left\langle f_{\mathrm{ct}}\right\rangle$ is the vertically averaged liquid cloud fraction weighted by the total BC:

$$
\left\langle f_{\mathrm{ct}}\right\rangle=\left[\sum f_{\mathrm{liq}} \cdot q \cdot M\right] /\left[\sum q \cdot M\right]=\left[\sum f_{\mathrm{liq}} \cdot q \cdot M\right] / B
$$

where $f_{\text {liq }}$ is the liquid cloud fraction ${ }^{2}$ in a layer, $q$ is the total-BC mixing ratio, and $M$ is the air mass in the layer. The

\footnotetext{
${ }^{2}$ Liquid cloud fraction here means the subgrid fractional coverage of stratiform clouds that contain some liquid water, and may or may not be mixed phase.
}

first term on the right-hand side of Eq. (2) $\left(F_{\mathrm{w}} / B_{\mathrm{c}}\right)$ is the column-average first-order wet-removal rate for cloud-borne BC. At individual grid points, this rate is equal to the rate at which cloud water is converted to precipitation (by autoconversion and collection), as calculated in the cloud microphysics. The second term, $\left(B_{\mathrm{c}} /\left\langle f_{\mathrm{ct}}\right\rangle B\right)$, represents the ratio of cloud-borne to total $\mathrm{BC}$ within the subgrid areas occupied by liquid clouds. It is determined both by the activation efficiency for BC-containing particles and by the relative rates at which cloud-borne $\mathrm{BC}$ is wet-removed by precipitation versus replenished via activation. The third term, $\left\langle f_{\mathrm{ct}}\right\rangle$, calculated in the way described by Eq. (3), is BC-weighted liquid cloud fraction. Thus the three terms each represent a subset of the parameters that affect BC wet removal. The three terms are calculated from time-averaged quantities, so that the right-hand sides of Eqs. (1) and (2) are equal at each model grid point (or grid column). The terms could be calculated for each time step, and then averaged; this would give somewhat different results numerically and would violate the equality in Eq. (2). However, since the purpose of these diagnostic quantities is to provide insight into differences between models and simulations, and inform us of sources of uncertainty, these computational nuances are of secondary importance. BC-weighted cloud-average liquid water content (LWC) is calculated similar to Eq. (3) and is plotted in Fig. $1 \mathrm{~h}$.

Examination of these three decomposed terms reveals that BC-weighted liquid cloud fraction (term III, Fig. 1f) and cloud-borne BC first-order removal rate (term I, Fig. 1d) are both higher in CAM5std than in the MMF at mid- and high latitudes. It is the much-higher liquid cloud fraction and the more rapid removal of cloud-borne $\mathrm{BC}$ poleward of $35^{\circ} \mathrm{N}$ that explain the much-lower Arctic BC in standard CAM5. In comparison, the in-liquid-cloud cloud-borne aerosol fraction (term II, $B_{\mathrm{c}} /\left\langle f_{\mathrm{ct}}\right\rangle B$, Fig. 1e) differs less between the models over the $35^{\circ}-65^{\circ} \mathrm{N}$ latitude range. At high latitudes, 
term II is much smaller in CAM5std than the MMF. Term I and II tend to counteract each other at these latitudes, however, and the weighted liquid cloud fraction (term III) differences between the two models dominate at these latitudes. The much-smaller cloud-borne fraction (term II) north of $60^{\circ} \mathrm{N}$ is likely due to too-rapid removal of cloud drops (and cloud-borne aerosol) in CAM5std, and this rapid removal is associated with its much-lower LWC (Fig. 1h). The in-cloud wet-removal rate for cloud-borne $\mathrm{BC}$ is proportional to the precipitation production rate (from cloud water) in a layer, divided by the LWC, so LWC can strongly influence wet removal. Liu et al. (2011b) also found that CAM5 underpredicts liquid water in Arctic stratiform clouds, leading to overly rapid removal of cloud drops and cloud-borne aerosol.

\subsection{Model changes and simulation design}

Based on the model diagnoses shown above, and also the evaluation of upper-tropospheric BC in Liu et al. (2012), we design a set of simulations to investigate the CAM5 model sensitivity to some of its parameterizations and assumptions involving aerosol wet removal (through in-cloud and belowcloud scavenging) and convective transport that influence aerosol (BC in particular) reaching high latitudes and the upper troposphere. The simulations are described below and summarized in Table 1. Except for the model changes noted here, all other setting in these sensitivity simulations are identical to those used in the CAM5std simulation described in Sect. 2.2. Note that the default 3-mode aerosol treatment is used unless otherwise specified in the name.

\subsubsection{CTRL}

An inconsistency involving the subgrid cloud fraction for liquid-containing clouds used in the droplet nucleation routine versus the other cloud micro- and macrophysics routines was eliminated. At colder temperatures, the liquid cloud fraction used in aerosol activation calculations is considerably overestimated in CAM5std, and the inconsistency fix reduces the liquid cloud fraction. This CTRL simulation was primarily designed to serve as a better baseline for the other sensitivity tests (below), all of which include this change.

\subsubsection{CONV}

The new unified treatment of aerosol vertical transport and in-cloud wet removal by convective clouds (but with aerosol activation in updrafts only at cloud base) replaces the standard CAM5 treatment. Cloud-borne aerosols in convective clouds are treated explicitly, with aerosol activation at cloud base calculated using the Abdul-Razzak and Ghan (2000) parameterization. In-cloud wet scavenging and vertical transport of aerosols are treated simultaneously in the new scheme (see Supplement Sect. S1), which results in convective wet scavenging now affecting the grid-cell mean aerosols primarily at detrainment levels rather than throughout the cloud depth. This model change, which represents an improved formulation, exposes the sensitivity of remote aerosols (upper troposphere and high latitudes) to convective cloud processes. Note that the change does not directly impact the model's convective cloud parameterizations involving heat, moisture and momentum.

\subsubsection{CONV_sact}

This simulation includes changes for CONV, but secondary activation of aerosols entrained into convective updrafts (in addition to the primary activation at cloud base), followed by their in-cloud wet removal, is also included. This secondary activation increases in-cloud wet removal and reduces transport to the upper troposphere. This simulation investigates sensitivity of aerosol fields to the secondary activation, a process in which the correct treatment is quite uncertain in our model and all other GCMs.

\subsubsection{CONV_FD}

The fractional areal extent of stratiform liquid-containing clouds at cold temperatures is reduced. The observationally based study of Garrett et al. (2011) indicated that highlatitude aerosols are sensitive to clouds with these characteristics, and this is also supported by the comparison between CAM5 and MMF. We explore this sensitivity by varying parameters associated with the stratiform cloud macrophysics, using the "freeze-dry" parameterization of Vavrus and Waliser (2008) that was already present in CAM5. It reduces liquid cloud fraction by a factor of $q_{v} / q_{v 0}$ when the ambient specific humidity $q_{v}$ is smaller than a threshold $q_{v 0}=0.006 \mathrm{~kg} \mathrm{~kg}^{-1}$. (This $q_{v 0}$ is doubled from Vavrus and Waliser, 2008). Note that alternate approaches for achieving this effect may be more desirable. Model changes in CONV are also included.

\subsubsection{CONV_SF}

Sensitivity of aerosols to stratiform cloud wet-removal rates is investigated by lowering the stratiform in-cloud wetremoval adjustment factor from 1.0 to 0.6 . Conceptually, this can be viewed as lowering one or more of the parameters that determine stratiform in-cloud wet removal (liquid cloud fraction, aerosol activation, and cloud-water removal rate). In particular, the cloud-water removal rate, determined by the stratiform micro- and macrophysics parameterizations, was found to be too rapid in CAM5 (Wang et al., 2012). Model changes in CONV are also included.

\subsubsection{CONV_m7}

Sensitivity of BC (and POM) aerosol to the treatment of aging is investigated. Liu et al. (2012) and numerous previous studies have demonstrated how the treatment of aging affects wet removal and long-range transport. This simulation uses 
the 7-mode aerosol treatment (MAM7) of CAM5 along with the slow-aging assumptions from Liu et al. (2012): the aging criterion for $\mathrm{BC}$ and $\mathrm{POM}$ in the primary carbon mode is 8 monolayers of condensed sulphate (or an equivalent amount of SOA), and the POM hygroscopicity is zero. Model changes in CONV are also included, allowing comparison of the impact of slow aging on aerosol fields to that of the other model changes.

\subsubsection{ALL_m3}

This simulation includes all changes specifically made in CTRL, CONV, CONV_sact, CONV_FD and CONV_SF simulation to show their combined effect for the 3-mode aerosol treatment.

\subsubsection{ALL $\mathrm{m} 7$}

This includes all the changes in ALL_m3, but uses the 7mode aerosol treatment with slow aging, which is particularly important for $\mathrm{BC}$ transport to remote regions.

\section{Results and model evaluation}

The following sections describe how the modifications in formulations of wet removal and vertical transport change aerosol distribution in remote regions. Simulations are also compared and evaluated against long-term surface observations (in terms of monthly mean BC and sulphate concentrations) and aircraft measurements during field campaigns (in terms of BC vertical profiles). Simulations involving the new unified aerosol convective transport/removal scheme are particularly discussed to demonstrate the improvement of aerosol vertical distribution. The impact of model changes on global aerosol, cloud and precipitation properties is also evaluated.

\subsection{Importance of wet removal formulations to high-latitude aerosols}

Figure 2 shows the same quantities as in Fig. 1 but for the various CAM5 sensitivity simulations listed in Table 1, designed to expose cloud and aerosol sensitivities compared to CAM5std and MMF. All changes to the model increase BC burden at high latitudes, except for the unified convective scheme. Removing internal inconsistencies in the CAM5 cloud formulations (CAM5std vs. CTRL) decreases the liquid cloud fraction used for aerosol activation by factor of 3 at $90^{\circ} \mathrm{N}$ (Fig. 2f). As a result, the total-BC first-order removal rate $\left(R_{\mathrm{w}}\right)$ is significantly reduced, nearly tripling the $\mathrm{BC}$ burden in the Arctic. Introducing the improved convection treatment and aerosol secondary activation (in CONV and CONV_sact) affects low-latitude column burden and wetremoval rate, but has very limited impact on mid- and highlatitude BC.
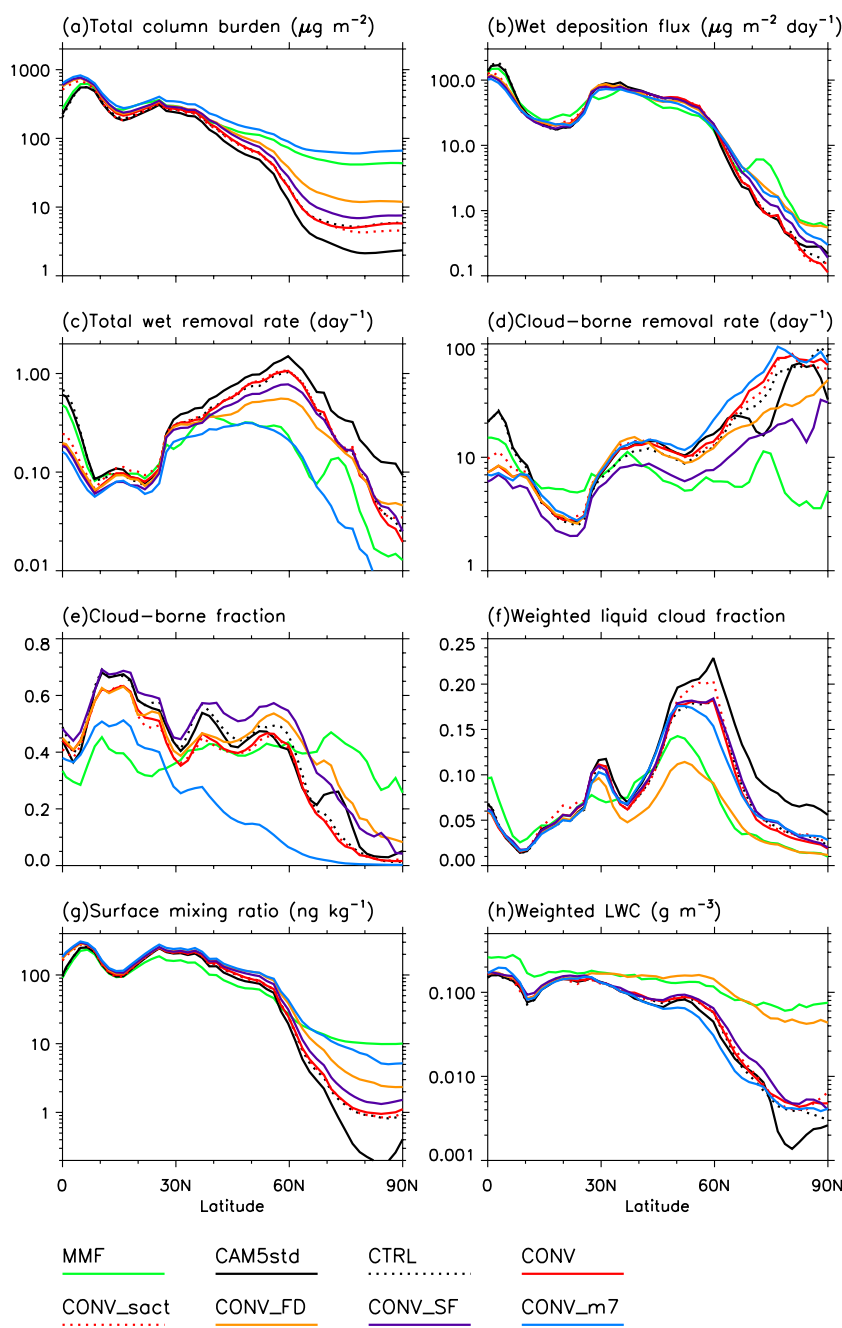

Fig. 2. Same as in Fig. 1 but including six more simulations listed in Table 1 and with a focus on the Northern Hemisphere.

Decreasing the frequency of occurrence of liquid clouds in the winter dry air through the freeze-dry scheme (CONV_FD) further reduces liquid cloud fraction poleward of $50^{\circ} \mathrm{N}$ (by a factor of 2) to the MMF level. This leads to a much-higher LWC (Fig. 2h), presumably caused by the Wegener-Bergeron-Findeisen process, in which ice particles grow at the expense of liquid droplets, operating in a smaller fractional area and having less impact. From about $35^{\circ}-65^{\circ} \mathrm{N}$, terms I and II combined are nearly identical in CONV and CONV_FD, so that the lower liquid cloud fractions (term III) are mainly responsible for lower total-BC first-order removal rates and higher burdens in CONV_FD (a factor of 2 at $65^{\circ} \mathrm{N}$ ). At higher latitudes, the cloud-borne $\mathrm{BC}$ fraction within liquid clouds (term II, Fig. 2e) becomes increasingly larger in CONV_FD; the total-BC first-order removal rate becomes close to (or exceeds) that in CONV. This again demonstrates that the role of the liquid cloud fraction is important but complex, and is not the only factor affecting 
$\mathrm{BC}$ wet removal at mid- and high latitudes. The interesting behavior at high latitudes may be important to the local BC removal and burden in the Arctic, but the results indicate that wet scavenging at mid-latitudes largely controls how much $B C$ gets to the Arctic.

Wet removal by stratiform clouds plays a dominant role in the long-range transport of $\mathrm{BC}$ to the Arctic. The in-cloud removal rate depends physically on the rate at which cloud water is converted to precipitation, which is probably too high in CAM5 with the current auto-conversion scheme (Wang et al., 2012); however, the CAM5 treatment of aerosol in-cloud wet removal also includes a tunable parameter, the stratiform in-cloud wet-removal adjustment factor. When this parameter is reduced from 1.0 (in CONV) to 0.6 in CONV_SF, the first-order removal rate for cloud-borne aerosols decreases significantly, and the cloud-borne aerosol lifetime and burden increase significantly. However, this decrease in cloudborne removal rate (term I) and increase in cloud-borne fraction (term II) counteract each other, so that the decreases in total wet-removal rate and the increases in total-BC burden are rather modest.

The CONV_m7 simulation has an explicit treatment of BC aging that significantly slows the in-cloud wet removal of freshly emitted BC. As shown in Fig. 2e, with the slower $\mathrm{BC}$ aging process, the $\mathrm{BC}$ cloud-borne fraction in CONV_m7 is significantly lower than in MMF and CONV from $30^{\circ} \mathrm{N}$ northwards. Although the liquid cloud fraction is still much higher (and LWC is much lower) in CONV_m7 than in the MMF, the total removal rate is close to MMF's at midlatitudes $\left(30^{\circ}-65^{\circ} \mathrm{N}\right)$, allowing for the transport of more $\mathrm{BC}$ to the Arctic. The $\mathrm{BC}$ burden is even higher than in the MMF at all latitudes and is about $50 \%$ higher in the Arctic. This suggests that the $\mathrm{BC}$ aging process is more influential than others in regulating $\mathrm{BC}$ wet removal in the CAM5 model.

\subsection{Improvements to aerosols in high-latitude remote regions}

Figure 3 compares model-simulated ( $10 \mathrm{yr}$ mean) and measured seasonal variations of near-surface $\mathrm{BC}$ mixing ratios at three sites in the Arctic and one in the Antarctic. Measurements that cover different time periods at the four polar sites are obtained from various sources: (a) Barrow and (b) Alert, 1989-2003, based on Sharma et al. (2006); (c) Zeppelin, 1998-2007, from Eleftheriadis et al. (2009); and (d) Halley (Antarctic), 1992-1995, from Wolff and Cachier (1998). Note that the available measurements were derived by converting aerosol light absorption to $\mathrm{BC}$ mass mixing ratios. Uncertainties in $\mathrm{BC}$ optical properties may contribute to an overestimation of BC mass by a factor of 1-3 (Vignati et al., 2010), although site-specific calibrations were sometimes done. Other light-absorbing aerosol species such as dust and organics can also cause an overestimation of BC mass (Shindell et al., 2008). Despite measurement uncertainties, it is clear that the CAM5std substantially underestimates BC in
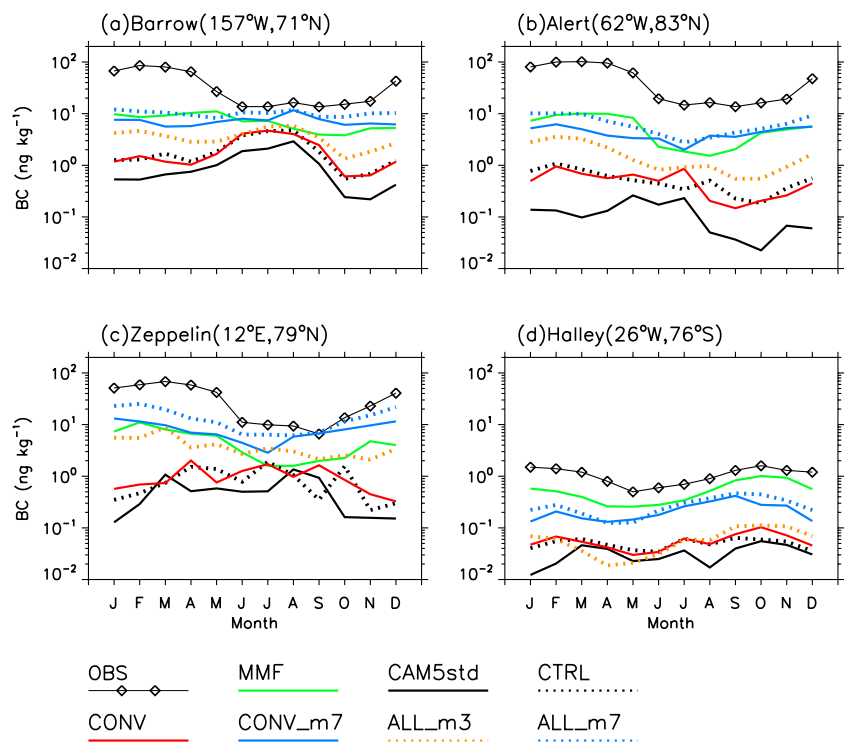

CTRL

CONV CONV_m7 ALL_m3 ALL_m7

Fig. 3. Observed and modeled monthly mean BC surface mixing ratios $\left(\mathrm{ng} \mathrm{kg}^{-1}\right)$ at the four polar sites: (a) Barrow, (b) Alert, (c) Zeppelin, and (d) Halley.

the remote Arctic region, like many other climate models (Shindell et al., 2008; Koch et al., 2009b). CAM5std underestimates BC by $\sim 3$ orders of magnitude in the Arctic haze season (i.e., winter and early spring), assuming the measurements are representative. The MMF is much closer to observations, although it also underestimates the surface $\mathrm{BC}$ mixing ratio by up to one order of magnitude at some of the locations in boreal winter and early spring. The seasonal cycle in CAM5std surface BC is also wrong: observations show a maximum in winter and early spring and a minimum in summer and fall, while the modeled maximum is in summer.

Modifications to improve model internal consistency in CTRL reduce liquid cloud fraction for aerosol activation and thus increase surface BC mixing ratios at all four sites, but have a minor impact on the seasonality (i.e., summer-winter contrast). The new convective processing (CONV, and also CONV_sact, not shown) has little impact on surface BC at these locations. Several other modifications to liquid clouds, wet removal, and $\mathrm{BC}$ aging significantly improve the prediction of both magnitude and seasonality. Reducing the stratiform in-cloud wet-removal adjustment factor (separately in CONV_SF, not shown) increases surface BC for all months, but has less impact on the seasonality. However, reduction of liquid cloud fraction in cold and dry environments (in CONV_FD, not shown) helps substantially with the seasonality and the Arctic haze season low bias. The more complete 7-mode aerosol module with slower $\mathrm{BC}$ aging produces the single biggest change to $\mathrm{BC}$ mixing ratios (CONV_m7 vs. CONV), even more substantial than the combination of other improvements (ALL_m3 vs. CONV). It also improves the seasonality, which is likely due to slower aging in winter 

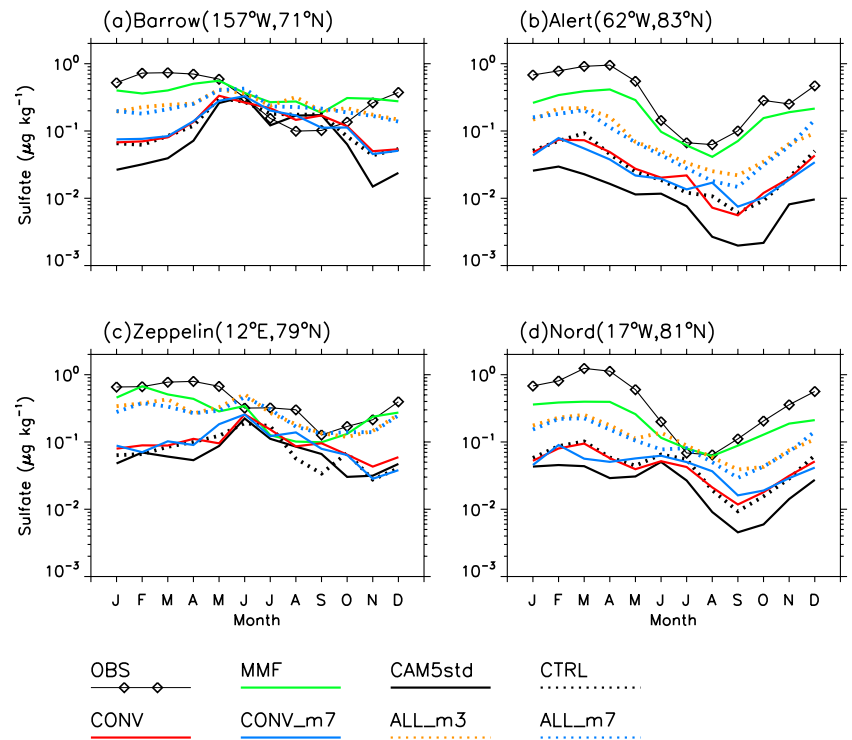

Fig. 4. Observed and modeled monthly mean non-sea-salt sulphate mixing ratios $\left(\mu \mathrm{g} \mathrm{kg}^{-1}\right)$ at the four Arctic sites: (a) Barrow, (b) Alert, (c) Zeppelin, and (d) Nord.

than in summer. The "best" combination of modifications in ALL_m7 gives BC mixing ratios comparable to, often times even higher than, the MMF's, although still lower than observations during the Arctic haze season.

Some of the modifications to CAM5 also affect the transport of other aerosol species to the Arctic. Figure 4 shows the seasonal cycles of sulphate mixing ratio as simulated in the various simulations and measured at four Arctic sites: (a) Barrow, 1997-2008 (Quinn et al., 2007); (b) Alert, 19952002 (data available through the Canadian National Atmospheric Chemistry Database and Analysis System); (c) Zeppelin, 1995-2005 (data available through the European Monitoring and Evaluation Programme (EMEP) database); and (d) Nord, Greenland, 1992-1995 (Heidam et al., 1999). Overall, sulphate mass mixing ratios in the CAM5std are also strongly underpredicted, especially during the haze season. They are substantially increased by the model improvements involving liquid cloud fraction and stratiform in-cloud wetremoval adjustment factor, but the new convective processing has little impact. Seasonality at Barrow and Zeppelin, which is poorly simulated in CAM5std, is somewhat improved in the ALL_m3 and ALL_m7 simulations.

Note that the 7-mode slower BC aging simulations (CONV_m7 and ALL_m7), which give the greatest improvement in simulated BC at high-latitude sites, do not improve sulphate mixing ratios relative to the 3-mode simulations (CONV and ALL_m3). This is not surprising, as the 7-mode treatment of $\mathrm{BC}$ (and $\mathrm{POM}$ ) and the slower aging criterion have little direct impact on sulphate, which is predominantly in the accumulation mode in both cases. In fact, sulphate mixing ratios in simulations with the 7-mode aerosol are often somewhat lower than the 3-mode simulations. The explicit treatment of ammonia/ammonium in the 7-mode simulations leads to more efficient aqueous conversion of $\mathrm{SO}_{2}$ to sulphate (Liu et al., 2012), less transport of $\mathrm{SO}_{2}$ to the Arctic, and less production of sulphate from $\mathrm{SO}_{2}$ there.

Sulphate mixing ratios at Alert, Barrow, and Zeppelin are simulated more accurately than $\mathrm{BC}$ mixing ratios when compared to the corresponding measurements, suggesting that the discrepancy in $\mathrm{BC}$ prediction is partially related to uncertainties in the $\mathrm{BC}$ measurements (i.e., the contamination by other light-absorbing species and the conversion of light absorption to mass mixing ratio) and/or BC emissions. However, there are significant differences in the sources and lifecycles of BC (a primary pollutant) and sulphate (a secondary pollutant) moving to the remote Arctic. Discrepancies in seasonality exist for both BC and sulphate (even in the MMF simulation), which are more likely due to the representation of associated aerosol-cloud processes in the model.

\subsection{Improvements to aerosol vertical transport and distribution}

It is important to simulate the correct vertical distribution of aerosols. Some aerosol species in the mid- and upper troposphere may affect ice cloud formation (e.g., Fan et al., 2012). Vertical distribution of light-absorbing aerosols, like BC, influences local radiative heating and, consequently, the thermodynamic structure and circulation. Here we take BC as an example (also due to the availability of observations) to evaluate the impact of model modifications on aerosol vertical distribution.

As shown in Fig. 5, the zonal average vertical distribution of the $\mathrm{BC}$ mixing ratio from the CAM5std simulation shows a very different vertical structure compared to the MMF simulation, not just at high latitudes where $\mathrm{BC}$ mixing ratios are much lower in CAM5std at all levels. Additionally, the Arctic $\mathrm{BC}$ mixing ratio is greatest in the upper troposphere in the CAM5std simulation. Improvements in the CTRL simulation increase $\mathrm{BC}$ over high-latitude regions, but the features in the upper troposphere still exist. The unified treatment of convective transport and in-cloud wet removal (in CONV) has little impact on the Arctic $\mathrm{BC}$ mixing ratios (compared to CTRL), but it significantly increases tropical $\mathrm{BC}$ mixing ratios below $600 \mathrm{hPa}$. This is because convective in-cloud wet removal in the new treatment is applied to aerosol in updrafts (which would otherwise be transported out of these levels) and thus mostly reduces grid-cell mean aerosol concentrations at detrainment levels, while convective wet removal in the older treatment removes aerosols at these levels $(<600 \mathrm{hPa})$ before the transport. When including aerosol secondary activation in the new convective transport scheme (CONV_sact), the upper-troposphere BC peak over the Arctic and lower latitudes is eliminated.

The 7-mode aerosol scheme plus slower BC aging allows for more $\mathrm{BC}$ being transported to the mid- and upper 

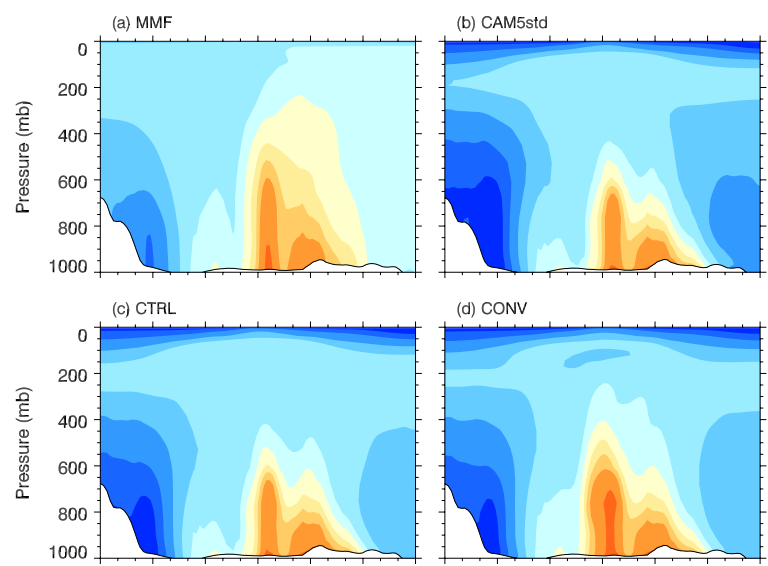

(d) CONV
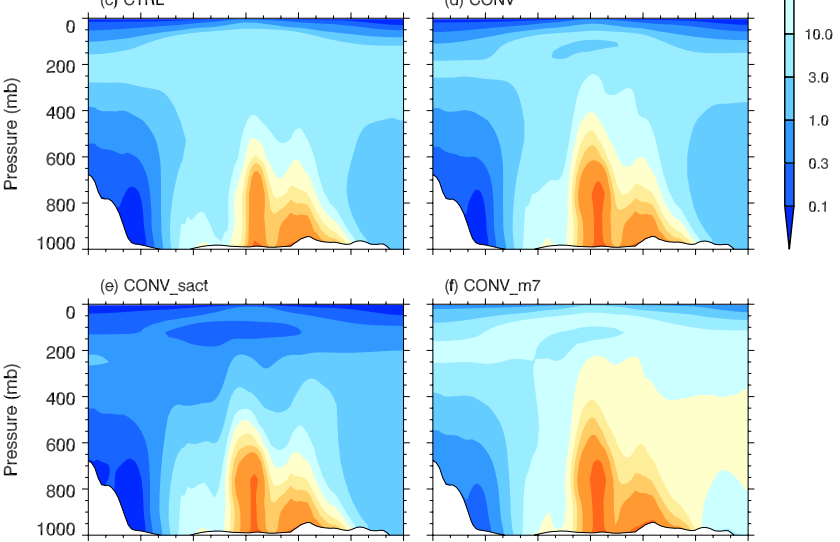

(f) CONV_m7
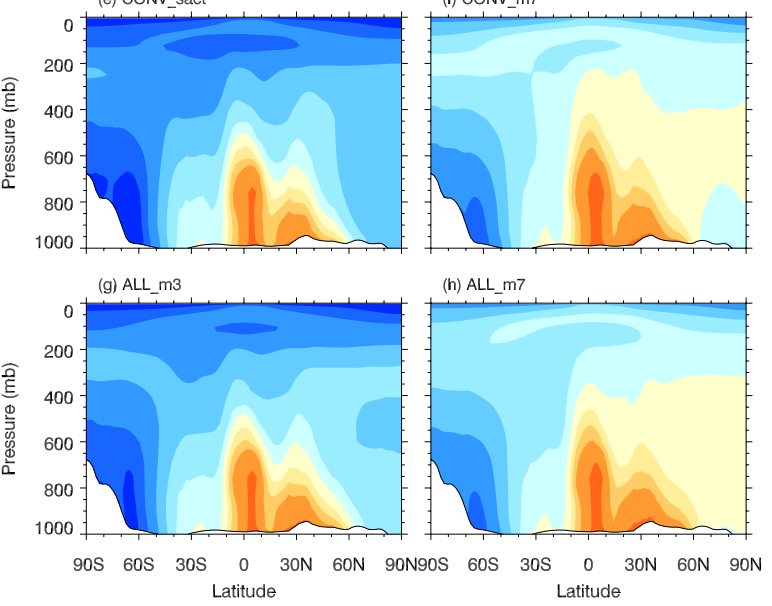

Fig. 5. Vertical and meridional distribution of DJF zonal-mean BC mass mixing ratios ( $\mathrm{n} \mathrm{kg}^{-1}$ ) from the various simulations. White areas between the black line and horizontal axis indicate zonalmean topography.

troposphere and to high latitudes (CONV_m7 vs. CONV). The individual cross-sections of accumulation mode and primary carbon mode BC for CONV_m7 (not shown) suggest that the Arctic BC in CONV_m7 is mostly transported in the primary carbon mode originating from mid-latitudes $\left(30^{\circ}-\right.$ $60^{\circ} \mathrm{N}$ ). The aging is slow enough to allow considerably more upward and poleward transport. Further combining with the aforementioned modifications related to wet removal increases BC mixing ratios almost everywhere (ALL_m7 vs. CONV_m7).

Figures 6, 7 and 8 compare vertical profiles of BC mixing ratios from selected model simulations to observations from the first HIAPER Pole-to-Pole Observations campaign (HIPPO1) in January 2009 (Schwarz et al., 2010) and from field campaigns at other locations and times (Koch et al., 2009b). The observed profiles represent averages of high temporal/spatial resolution measurements along flight tracks in certain latitude-longitude ranges (a profile may contain observations from just one or two flights or from several
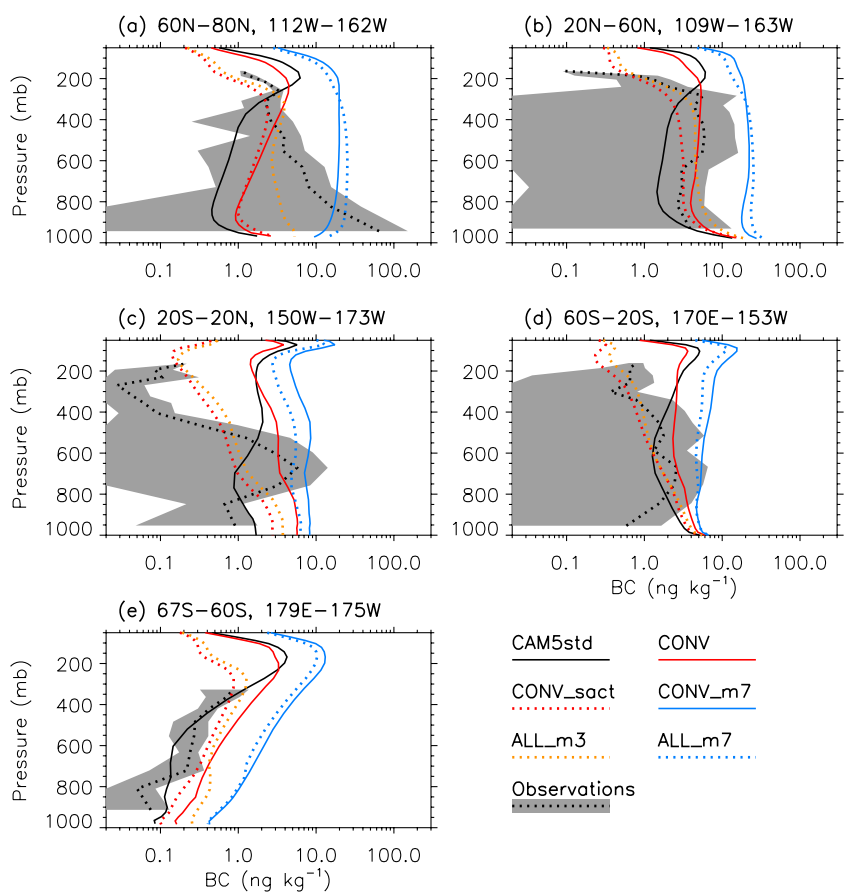

Fig. 6. Vertical profiles of $\mathrm{BC}$ mass mixing ratios $\left(\mathrm{ng} \mathrm{kg}^{-1}\right)$ from HIPPO1 observations in January 2009 (dotted lines for the mean along flight tracks; shaded area representing one standard deviation on each side of the mean) and model simulations (colored lines for simulations described in Table 1). Profiles from model output (10 yr January mean) are sampled along flight tracks within the latitudelongitude range for each panel.

flights), while model profiles are sampled from climatological $(10 \mathrm{yr})$ monthly means at closest proximity to flight locations and times. As argued by Koch et al. (2009b), there are some potential problems for detailed comparison of temporally/spatially resolved observations to model monthly means; nevertheless, some useful broad tendencies can be derived from the comparison.

The standard CAM5 simulation (CAM5std) shows varying performance in comparison to the observations. $\mathrm{BC}$ mixing ratios are too low in the Arctic in winter (Fig. 6a) and spring (Fig. 8a-c). They are also too high in the upper troposphere and lower stratosphere (UTLS) in the tropics (Figs. 6c and $7 \mathrm{~b}$ and c) and some mid-latitudes (Figs. 6d and 7a). There is a consistent UTLS maximum that is more pronounced than in the observations. Koch et al. (2009b) found that the AeroCom models also have high biases (exceeding mean plus one standard deviation of observations) at higher altitudes in the tropics and mid-latitudes.

The new treatment of convective processing with secondary activation (CONV_sact) transports much less BC to the UTLS and noticeably reduces the high bias and maximum there. Without secondary activation (CONV), the BC high bias in the UTLS is somewhat reduced, but the maximum is still close to the standard CAM5. Above-cloud-base 
(a) AVE Houston, November

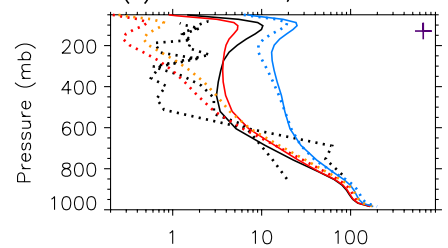

(c) TC4, August
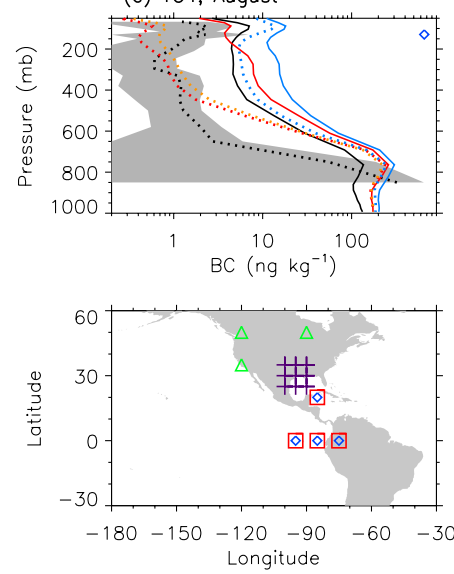

(b) CR-AVE, February

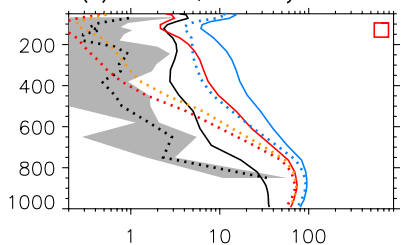

(d) CARB, June

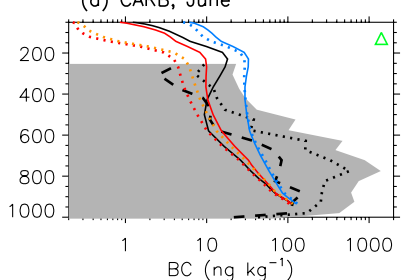

CAM5std

CONV_soct

CONV

ALL $m 3$

CONV_m7

ALL_m3

ALL_m7

Observations

Fig. 7. Same as Fig. 6 but for different locations (the tropics and mid-latitudes) and months. Black dashed line (if present) is the median profile of observed BC $\left(\mathrm{ng} \mathrm{kg}^{-1}\right)$. In (a) the two black dotted lines are for two sampling days. Biomass burning was encountered in (d). Symbols over the map in the bottom panel indicate the approximate geographical location of the observed profiles for each field campaign, and simulated profiles represent averages over these locations. More information about the observations is available in Koch et al. (2009b; Fig. 9 and Table 7).

entrainment accounts for a significant fraction of the updraft mass flux in the CAM5 deep convection treatment, and, without secondary activation, $\mathrm{BC}$ entrained above cloud base is transported upwards rather than being activated and removed. The somewhat-higher BC in the lower and mid-troposphere with CONV and CONV_sact (compared to CAM5std) is largely due to the changes in liquid cloud fraction implemented in CTRL (not shown), except in the tropics. Additional model changes in ALL_m3 (involving reduced liquid cloud fraction and stratiform in-cloud wet-removal adjustment factor) further increase lower to mid-troposphere $\mathrm{BC}$, particularly in the Arctic winter and spring profiles (Figs. 6a and 8a-c).

In the 7-mode slow-aging simulations (CONV_m7 and ALL_m7), BC increases noticeably in all the profiles compared to the corresponding 3-mode simulations (CONV and ALL_m3), and the UTLS maximum re-appears. These increases reduce the Arctic low biases for spring (Fig. 8a-c) and winter (Fig. 6a, lower troposphere only), but the simulated BC is too high for many of the profiles (Figs. 6b-e and $7 \mathrm{a}$ and $\mathrm{b}$ ). Compared to the HIPPO1 observations, Schwarz et al. (2010) showed that the ensemble mean of the AeroCom

(a) ARCTAS DC-8, April

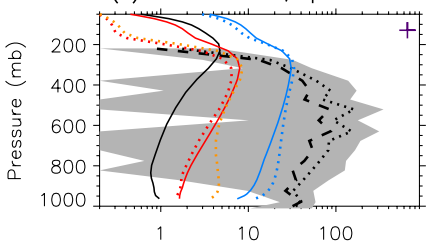

(c) ARCPAC, April

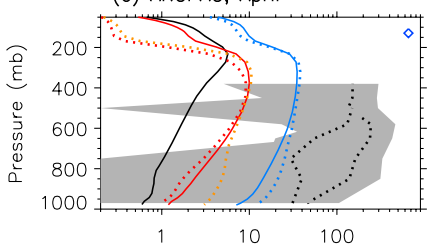

(e) ARCTAS P3-B, June-July

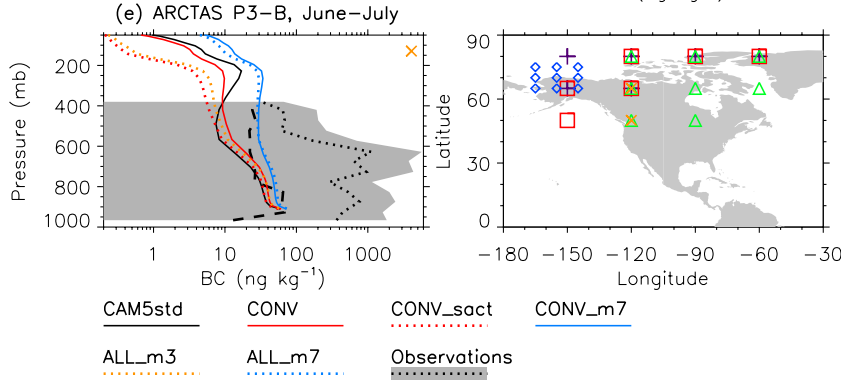

Fig. 8. Same as Fig. 7 but for the high latitudes over North America. In (c), the higher BC mixing-ratio profile $\left(\mathrm{ng} \mathrm{kg}^{-1}\right)$ is for flights that sampled episodic biomass burning plumes, and the lower mixingratio profile is for aged Arctic air. The mean profiles in (d) and (e) were also affected by summer smoke plumes.

suite of global model simulations (using different BC emissions; Dentener et al., 2006) overestimated BC by a factor of 5, on average, for the entire dataset. For the CAM5std, CONV_sact, ALL_m3, and ALL_m7 simulations, the median ratios of simulated to observed $\mathrm{BC}$ are 1.1, 0.9, 1.0, and 7.2, respectively. The CONV_sact and ALL_m3 do moderately well by these metrics (even though strongly underpredicting $\mathrm{BC}$ in the Arctic lower troposphere), while the 7-mode slowaging simulation overpredicts $\mathrm{BC}$ because of too-slow wet removal and too much vertical transport.

Despite strong discrepancies in magnitudes for some BC profiles, the CAM5 simulations capture the observed lowerto-mid-troposphere $\mathrm{BC}$ structure reasonably well in most cases (Fig. 6a being a notable exception). In the tropics and mid-latitudes, the $\mathrm{BC}$ mixing ratio decreases from the lowertroposphere maximum all the way to mid- and upper troposphere. A similar trend holds for the Arctic in boreal summer, while an opposite trend emerges in the Arctic spring (Fig. 8a-c) and the near-Antarctic in January (Fig. 6e). Many AeroCom models, as seen in Koch et al. (2009b), were not able to capture this vertical structure change between spring and summer in the Arctic. 
Table 2. Global annual BC budgets in MMF and CAM5 simulations.

\begin{tabular}{lrrrr}
\hline Simulation & $\begin{array}{r}\text { Wet deposition } \\
\left(\mathrm{TgC} \mathrm{yr}^{-1}\right)\end{array}$ & $\begin{array}{r}\text { Dry deposition } \\
\left({\left.\mathrm{Tg} \mathrm{C} \mathrm{r}^{-1}\right)}\right)\end{array}$ & $\begin{array}{r}\text { Burden } \\
(\mathrm{Tg} \mathrm{C})\end{array}$ & $\begin{array}{r}\text { Lifetime } \\
(\text { day })\end{array}$ \\
\hline MMF & 6.03 & 1.70 & 0.140 & 6.6 \\
CAM5std & 6.44 & 1.33 & 0.083 & 3.9 \\
CTRL & 6.40 & 1.36 & 0.091 & 4.3 \\
CONV & 6.32 & 1.43 & 0.111 & 5.2 \\
CONV_sact & 6.37 & 1.37 & 0.090 & 4.2 \\
CONV_FD & 6.29 & 1.45 & 0.112 & 5.3 \\
CONV_SF & 6.22 & 1.52 & 0.123 & 5.8 \\
CONV_m7 & 5.98 & 1.77 & 0.168 & 7.9 \\
ALL_m3 & 6.26 & 1.48 & 0.099 & 4.7 \\
ALL_m7 & 5.90 & 1.84 & 0.158 & 7.5 \\
\hline
\end{tabular}

\subsection{Impact of model changes on global aerosol budgets and distributions}

Tables 2 and 3 summarize the impact of model changes on the global BC and non-sea-salt sulphate budget, respectively. All the modifications increase $\mathrm{BC}$ and sulphate burden directly or indirectly by reducing wet-deposition rates and increasing aerosol lifetimes.

Correcting the inconsistency involving liquid-containing cloud fraction within the model (CTRL simulation) increases global annual BC and sulphate burden by about $10 \%$. The new unified convective transport and wet removal scheme without secondary activation (CONV) further increases the annual BC burden by $22 \%$ and sulphate burden by $45 \%$. However, the unified convective scheme with secondary activation (CONV_sact), and thus more in-cloud wet removal, introduces almost no BC burden change and a much-smaller sulphate burden change relative to CTRL. The larger burden changes for sulphate vs. BC are due to different vertical profiles (sulphate mixing ratio generally decreases more slowly with height than does $\mathrm{BC}$ ), and to the wet removal in the mid-troposphere being relatively weak in the new convective treatment compared to the older one. Reducing liquid cloud fraction under cold/dry conditions using the freeze-dry scheme (CONV_FD) substantially increases atmospheric BC and sulphate burden in high latitudes, but it has little impact on the global annual burden that is dominated by sources and sinks at lower and mid-latitudes. Reducing the stratiform incloud wet-removal adjustment factor (CONV_SF) has limited impact on the annual burden, because the stratiform wet removal decrease is compensated by increases in convective wet removal and dry deposition.

Note that the total source for sulphate differs among the simulations because of differences in $\mathrm{SO}_{2}$ conversion to sulphate versus $\mathrm{SO}_{2}$ wet and dry removal. The $\mathrm{SO}_{2}$ aqueous conversion is much stronger in the MMF, so its total source (59.8 $\mathrm{Tg} \mathrm{S} \mathrm{yr}^{-1}$ ) and burden for sulphate are considerably higher than in the CAM5std (Wang et al., 2011b) and the sensitivity simulations, although the higher MMF burden is
Table 3. Global annual (non-sea-salt) sulphate aerosol budgets in MMF and CAM5 simulations.

\begin{tabular}{lrrrr}
\hline Simulation & $\begin{array}{r}\text { Wet deposition } \\
\left(\mathrm{Tg} \mathrm{S} \mathrm{yr}^{-1}\right)\end{array}$ & $\begin{array}{r}\text { Dry deposition } \\
\left(\mathrm{Tg} \mathrm{S} \mathrm{yr}^{-1}\right)\end{array}$ & $\begin{array}{r}\text { Burden } \\
(\mathrm{Tg} \mathrm{S})\end{array}$ & $\begin{array}{r}\text { Lifetime } \\
(\text { day })\end{array}$ \\
\hline MMF & 50.84 & 8.97 & 1.014 & 6.2 \\
CAM5std & 37.74 & 4.96 & 0.438 & 3.7 \\
CTRL & 37.67 & 5.10 & 0.493 & 4.2 \\
CONV & 37.41 & 5.86 & 0.714 & 6.0 \\
CONV_sact & 37.74 & 5.56 & 0.595 & 5.0 \\
CONV_FD & 37.49 & 6.06 & 0.721 & 6.0 \\
CONV_SF & 36.20 & 6.54 & 0.804 & 6.9 \\
CONV_m7 & 39.97 & 6.29 & 0.709 & 5.6 \\
ALL_m3 & 36.62 & 6.49 & 0.678 & 5.7 \\
ALL_m7 & 38.88 & 7.10 & 0.688 & 5.5 \\
\hline
\end{tabular}

partly due to longer sulphate lifetime (from slower wet removal).

Slower BC aging by itself causes a substantial increase in global BC burden. Both ALL_m7 and CONV_m7 have BC burdens $(0.16-0.17 \mathrm{Tg} C)$ and lifetimes (7.5-7.9 days) that are close to some previous studies (e.g., Textor et al., 2007; Koch et al., 2009b; Liu et al., 2011a) that used similar BC emission inventories. In comparison, the ALL_m3 (no BC aging but other improvements) has $37 \%$ smaller burden and lifetime. Other studies with somewhat-higher emissions produced $\mathrm{BC}$ burdens of $0.2-0.3 \mathrm{Tg} \mathrm{C}$. In the first AeroCom intercomparison (Textor et al., 2006), the median emissions, burden, and lifetime were $11.3 \mathrm{TgC}^{-1}, 0.21 \mathrm{TgC}$, and 6.54 days, respectively. With $\mathrm{BC}$ emission of $10.9 \mathrm{Tg} \mathrm{C} \mathrm{yr}^{-1}$, Huang et al. (2010) estimate an annual average BC burden of $0.28 \mathrm{Tg} \mathrm{C}$ and lifetime of 9.2 days. Actual $\mathrm{BC}$ burdens may be even higher, as Koch et al. (2009b) showed that for the AeroCom models the simulated column BC burden over six regions is about half of that estimated from AERONET retrievals.

We also compare monthly aerosol optical depth (AOD) and aerosol absorption optical depth (AAOD) at $550 \mathrm{~nm}$ predicted by CAM5 to AERONET retrievals for the years of 1998-2005 (e.g., Liu et al., 2012). Global and regional means are summarized in Table 4. The CAM5std strongly underestimates AOD and AAOD in all of the regions. AOD and AAOD increase by varying degrees in other simulations, consistent with the trends in $\mathrm{BC}$ and sulphate burdens (Tables 2 and 3), suggesting that the modifications to CAM5 aimed to improve aerosols in remote regions improve the simulation of aerosols in near-source regions as well. The dramatic increase in AOD and AAOD in simulations with 7-mode slow aging (ALL_m7 vs. ALL_m3) is primarily due to higher BC and POM burdens in some regions, although higher dust burdens simulated by MAM7 (due to differences in the finemode dust treatments, Liu et al., 2012) also contribute, especially in N. Africa.

In Liu et al. (2012) and Wang et al. (2011a), simulated $\mathrm{BC}$ concentrations were compared to observations from the 
Table 4. Global and regional mean observed and simulated AOD and AAOD (in parentheses). Observed values are from AERONET sites. Number of sites for each region is also in parentheses.

\begin{tabular}{|c|c|c|c|c|c|c|c|c|}
\hline Case & $\begin{array}{r}\text { E. Asia } \\
\text { (11) }\end{array}$ & $\begin{array}{r}\text { S. Asia } \\
\text { (5) }\end{array}$ & $\begin{array}{r}\text { Europe } \\
(14)\end{array}$ & $\begin{array}{r}\text { N. Africa } \\
(6)\end{array}$ & $\begin{array}{r}\text { S. Africa } \\
\text { (3) }\end{array}$ & $\begin{array}{r}\text { N. America } \\
(23)\end{array}$ & $\begin{array}{r}\text { S. America } \\
\text { (4) }\end{array}$ & $\begin{array}{r}\text { Global } \\
\text { (75) }\end{array}$ \\
\hline Observed & $0.339(0.027)$ & $0.391(0.041)$ & $0.183(0.015)$ & $0.515(0.046)$ & $0.183(0.021)$ & $0.133(0.007)$ & $0.208(0.024)$ & $0.213(0.017)$ \\
\hline CAM5std & $0.134(0.017)$ & $0.090(0.010)$ & $0.080(0.009)$ & $0.286(0.032)$ & 0.075 (0.009) & $0.066(0.006)$ & $0.100(0.008)$ & $0.111(0.012)$ \\
\hline CTRL & $0.158(0.020)$ & $0.093(0.010)$ & $0.093(0.010)$ & $0.287(0.032)$ & $0.078(0.010)$ & $0.074(0.007)$ & $0.103(0.008)$ & $0.122(0.013)$ \\
\hline CONV & $0.180(0.020)$ & $0.157(0.012)$ & $0.112(0.010)$ & $0.410(0.041)$ & $0.092(0.011)$ & $0.095(0.008)$ & $0.155(0.011)$ & $0.153(0.014)$ \\
\hline CONV_sact & $0.165(0.019)$ & $0.131(0.011)$ & $0.100(0.010)$ & $0.360(0.036)$ & $0.081(0.010)$ & $0.086(0.007)$ & $0.126(0.009)$ & $0.136(0.013)$ \\
\hline CONV_FD & $0.190(0.021)$ & $0.156(0.013)$ & $0.113(0.010)$ & $0.404(0.041)$ & $0.093(0.011)$ & $0.096(0.008)$ & $0.152(0.011)$ & $0.154(0.014)$ \\
\hline CONV_SF & $0.217(0.024)$ & $0.191(0.015)$ & $0.128(0.011)$ & $0.455(0.047)$ & $0.107(0.012)$ & $0.110(0.009)$ & $0.182(0.013)$ & $0.175(0.016)$ \\
\hline CONV_m7 & $0.236(0.028)$ & $0.197(0.018)$ & $0.142(0.013)$ & $0.562(0.050)$ & $0.133(0.014)$ & $0.137(0.011)$ & $0.219(0.016)$ & $0.204(0.019)$ \\
\hline ALL_m3 & $0.197(0.022)$ & $0.154(0.012)$ & $0.122(0.011)$ & $0.408(0.042)$ & $0.093(0.011)$ & $0.102(0.008)$ & $0.147(0.010)$ & $0.159(0.015)$ \\
\hline ALL_m7 & $0.254(0.029)$ & $0.191(0.017)$ & $0.164(0.015)$ & $0.557(0.050)$ & $0.126(0.013)$ & $0.142(0.012)$ & $0.202(0.014)$ & $0.210(0.019)$ \\
\hline
\end{tabular}

IMPROVE and EMEP networks. The surface BC concentrations in our simulations are also compared to observations from four networks or compilations (see Table S1 in the Supplement). The changes between the various simulations are considerably smaller at these surface sites than the changes to the global annual burdens (Table 2). This is not surprising for the IMPROVE (continental US), EMEP (Europe), and China sites, which are relatively close to sources (on a global scale). The simulated values for the base model configurations are lower than observed, so model changes that increase BC burden and transport to the Arctic also reduce the CAM5 low bias for these datasets. All the simulations strongly underestimate the China observations, suggesting that $\mathrm{BC}$ emissions for this region may be significantly underestimated.

Similar information for surface sulphate concentrations, using observations from the IMPROVE, EMEP, and U. Miami (marine sites) networks, is provided in the Supplement (Table S2). The changes between the various simulations are larger than those for BC, but the changes are still smaller than the global annual burden changes. As with $\mathrm{BC}$, the changes increase sulphate mixing ratios, which increase the high bias for the IMPROVE and EMEP continental sites, but improve (and even reverse) the low bias for the remote marine sites.

\subsection{Impact of model changes on clouds and precipitation}

Figure 9 compares meridional distributions of annual zonalmean cloud liquid water path (LWP), ice water path (IWP), precipitation rate and cloud forcing from the various simulations. Differences relative to the CAM5std are plotted to illustrate the changes between simulations. Global mean values are summarized in Table S3. Comparing to observations used in Wang et al. (2011b; and references therein), global annual mean values are improved to varying degrees by the modifications to the CAM5std. Model biases in LWP and precipitation rate are reduced. Mean LWP becomes closer to, if not within, the observed range of $50-84 \mathrm{~g} \mathrm{~m}^{-2}$. IWP has much-smaller variation between the CAM5 simulations.
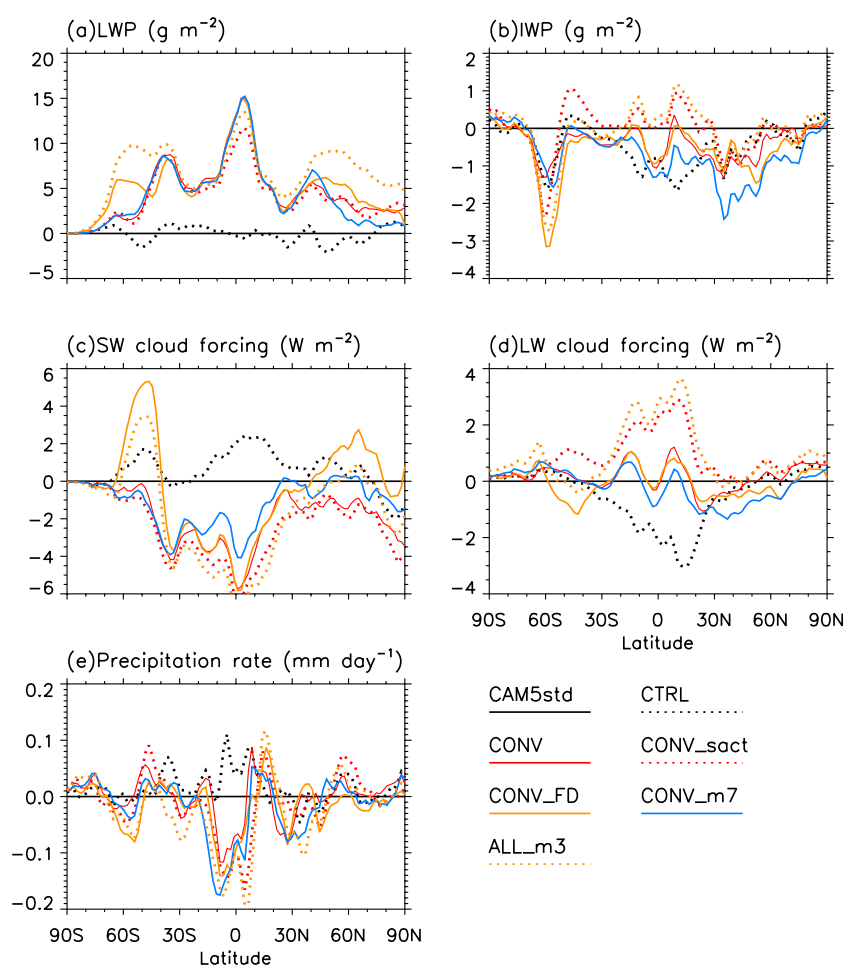

ALL_m3

Fig. 9. Meridional variation of annual mean differences (sensitivity simulation minus CAM5std) of (a) liquid water path (LWP, $\mathrm{g} \mathrm{m}^{-2}$ ), (b) ice water path (IWP, $\mathrm{g} \mathrm{m}^{-2}$ ), (c) total precipitation rate $\left(\mathrm{mm} \mathrm{day}^{-1}\right)$, (d) shortwave cloud forcing, and (e) longwave cloud forcing for the various simulations.

There is no direct measurement of cloud IWP for comparison, but Wang et al. (2011b) evaluated the total frozen water path in CAM5 against various satellite observations (and the MMF) and found that it is generally within the broad range of observations. Mean precipitation rate is slightly reduced but still higher than the Global Precipitation Climatology Project (GPCP) mean of $2.61 \mathrm{~mm} \mathrm{day}^{-1}$ for the years 1979-2003 (Adler et al., 2003). Mean values of shortwave and longwave 
cloud forcing are strengthened by most of the model changes, with SWCFs all in the observed -46 to $-53 \mathrm{~W} \mathrm{~m}^{-2}$ range, and LWCFs mostly closer to the observed 27 to $31 \mathrm{~W} \mathrm{~m}^{-2}$ range.

The CAM5std simulates a much-smaller global mean LWP $\left(41.2 \mathrm{~g} \mathrm{~m}^{-2}\right)$ than the observed range, which implies too-rapid conversion of cloud water to precipitation and is consistent with the too-strong wet removal of $\mathrm{BC}$ and other aerosols. The new treatment of convective transport and wet removal (in CONV) increases LWP by up to $15 \mathrm{~g} \mathrm{~m}^{-2}$ near the Equator, $3 \mathrm{~g} \mathrm{~m}^{-2}$ in the Arctic (which is substantial there), and $5.9 \mathrm{~g} \mathrm{~m}^{-2}$ globally, with about $75 \%$ of the increase in stratiform clouds. With aerosol secondary activation in convective clouds, the increase in LWP (CONV_sact vs. CTRL) is somewhat less. Other changes (CONV_FD and CONV_SF) further increase LWP. Most of the model improvements (except for the freeze-dry scheme) involve changes to the treatments of aerosol aging, activation, wet removal, and/or convective transport, rather than directly to the cloud macro- and microphysics. The resulting LWP increases are thus due to aerosol indirect effects, and probably the reason that LWP has a high sensitivity to aerosol loading in CAM5 (Wang et al., 2011b). This can also have feedback on aerosols because with higher liquid water the cloud-water removal rate and thus aerosol in-cloud scavenging in stratiform clouds are slower. Note that with slow aging, BC and POM concentrations are higher, but POM hygroscopicity is lower (zero), resulting in small decreases in cloud condensation nuclei $(\mathrm{CCN})$ and LWP.

There are also changes in IWP (Fig. 9b), likely caused by changes to liquid water in mixed-phase clouds and to global distributions of aerosols that act as ice nuclei (particularly in the upper troposphere and the Arctic). Along with the LWP changes, they affect both SW and LW cloud forcings, having implications for aerosol indirect forcing in the modified CAM5 model.

\section{Discussion and conclusions}

Many global aerosol and climate models, including the Community Atmosphere Model version 5 (CAM5), produce relatively poor simulations of aerosols in remote regions (i.e., high latitudes and upper troposphere) compared to regions close to major sources. In this study we have evaluated (and in some cases improved) process representations associated with aerosol-cloud interactions, cloud microphysics and macrophysics, aerosol transformation, convective transport and aerosol wet removal in CAM5 that are key to determining the amount of aerosols reaching remote regions. Sensitivity simulations were analyzed to understand the role of each of the processes and to identify sources of uncertainties. The evaluation and improvement were guided by surface and aircraft measurements together with results from the PNNL-MMF multi-scale aerosol-climate model, which has more-explicit representations of convection and the cloud processes that drive aerosol-cloud interactions. Our focus in the model evaluation was on $\mathrm{BC}$ aerosol, but the modifications have had a generally beneficial effect on the simulation of other aerosol species (e.g., sulphate) and of total AOD.

Wet removal is the dominant and most uncertain process in determining the atmospheric residence time of submicron aerosol particles and, therefore, the distance they can travel from sources during their lifetime. Wet removal in CAM5 consists of several mechanisms/processes that occur in and below convective and stratiform clouds. The most efficient wet-removal mechanism for submicron aerosol is nucleation scavenging in liquid clouds. At mid- and high latitudes during winter months, this primarily involves stratiform clouds. For this wet removal to take place, aerosol particles must be viable $\mathrm{CCN}$ and encounter a precipitating liquid-containing cloud. Thus the subgrid liquid cloud fraction is important in determining the fraction of aerosols that are activated and subsequently removed. Comparison with MMF suggests that the more frequent liquid-containing cloud at mid- and high latitudes simulated by CAM5 is a key contributor to the excessive removal of aerosols during their transport to the Arctic. Improving the internal consistency of the liquid cloud fraction used for aerosol activation and associated droplet nucleation in the standard CAM5 leads to nearly 3-fold increases in the Arctic BC burden in DJF months. Further reducing the amount of liquid-water-containing clouds under dry/cold conditions in CAM5 by an ad hoc solution (called "freeze-dry" by Vavrus and Waliser, 2008) doubles the BC burden in the high latitudes. With all improvements related to wet removal combined, the Arctic BC burden has a 10fold (5-fold) increase in the DJF (JJA) months, resulting in a better prediction of seasonal cycle as well. Arctic sulphate and dust burdens are also increased but to a lesser extent.

Another important process affecting $\mathrm{BC}$ wet removal is aerosol aging. The additional primary carbon mode in the more complete 7-mode aerosol module allows fresh BC particles to be transported with little scavenging until they age and grow into the accumulation mode. The slow-aging assumption (i.e., more hygroscopic material is needed to age a $\mathrm{BC}$ particle) results in slower aging in the model and extends BC lifetime in the atmosphere, allowing considerably more upward and poleward transport. In the cases considered, the global annual BC burden was increased from 0.11 to $0.17 \mathrm{Tg} \mathrm{C}$, and lifetime was extended from 5.2 to 7.9 days. In the simulation with slow BC aging (along with the improvements to wet removal), the Arctic DJF BC burden showed an additional 30-fold increase compared to the standard CAM5, and the JJA burden showed a 5-fold increase. These increases reduce the Arctic low biases for spring and winter; however, the 7-mode slow-aging assumption worsens the over prediction of upper-tropospheric BC because of too-slow wet removal and too much vertical transport. While several of our modifications have had a substantial impact on sulphate, which is also strongly underpredicted (but to a lesser extent 
than $\mathrm{BC}$ ) in the Arctic, the 7-mode slow-aging representation has minimal impact on sulphate. This suggests that the remaining low bias of Arctic BC in CAM5 is more likely contributed by processes other than the fast $\mathrm{BC}$ aging in the 3-mode aerosol module.

In-cloud wet scavenging of $\mathrm{BC}$ and other aerosol species in ice clouds is currently not treated in CAM5, because ice-nucleation scavenging affects a much-smaller number of particles than does droplet-nucleation scavenging. There is more uncertainty in how much BC is removed in ice clouds and mixed-phase clouds compare to liquid clouds. Cozic et al. (2007) measured $8 \%-17 \%$ removal by mixed-phase clouds relative to $60 \%$ removal by liquid clouds during winter at Jungfraujoch $\left(46.5^{\circ} \mathrm{N}, 8^{\circ} \mathrm{E}\right)$. Koch et al. (2009a) found that $12 \%$ removal by frozen precipitation relative to removal by liquid clouds in their model gave an optimal agreement with observations. Browse et al. (2012) found that suppressing ice-cloud scavenging in a global aerosol model results in a large increase in wintertime $\mathrm{BC}$ and the correct seasonal cycle. On the other hand, as discussed by Koch et al. (2009b), ignoring aerosol removal by ice may contribute to the excessive BC aloft. However, they also found that enhancing removal by convective clouds successfully reduced the BC aloft in the GISS model. In this study we also introduced a new unified scheme for convective transport and wet removal of aerosols in CAM5, with an option to treat secondary activation of aerosols entrained into convective clouds. This new scheme effectively reduces the BC aloft and better simulates the observed $\mathrm{BC}$ profiles with decreasing mixing ratios in the mid- to upper troposphere, especially in the tropics and mid-latitudes. Croft et al. (2012) also found that treatments of scavenging of aerosols entrained above cloud base strongly affect aerosol concentrations in the upper troposphere.

Despite all the model improvements, surface-level BC and sulphate mixing ratios at the remote Arctic sites are still significantly underpredicted, particularly for the winter and early-spring haze season. The long-term surface measurements cover different time periods for some sites, over which aerosol sources have likely changed. There are also many uncertainties in BC surface measurements (e.g., Shindell et al., 2008; Koch et al., 2009b; Vignati et al., 2010), which may explain part of the discrepancy, but there is likely more room for improvement in the long-range-transport-related processes in the CAM5 (e.g., Ma et al., 2013) and in the aerosol emission inventories used for the simulations (Lamarque et al., 2010). The global annual BC emissions for the year 2000 are about 7.8 $\mathrm{Tg} \mathrm{C} \mathrm{yr}^{-1}$, which is on the lower side of the range used by a variety of global models - for example, the diverse BC emission rates used by the AeroCom model intercomparison study range from 7.5 to $19 \mathrm{Tg} \mathrm{C} \mathrm{yr}^{-1}$ (Textor et al., 2006; Liu et al., 2011a), indicating large uncertainties in BC emission inventory. Bond et al. (2004) used bottom-up estimates of uncertainties in source strength to show that global annual BC emissions could range between 4.3 and $22 \mathrm{Tg} \mathrm{C} \mathrm{yr}^{-1}$. The regional distribution of emissions is also important for aerosols reaching remote regions such as the Arctic. In our sensitivity simulation with emission inventories for the year 1980 (see details in the Supplement), the global annual BC emission rate is lower, but the DJF BC emission rate over $40^{\circ}-70^{\circ} \mathrm{N}$ is $50 \%$ higher. The $50 \%$ higher $\mathrm{BC}$ emissions over $40^{\circ}-70^{\circ} \mathrm{N}$ translates to a $50 \%$ higher $\mathrm{BC}$ burden and $70 \%$ higher $\mathrm{BC}$ surface mixing ratio north of $50^{\circ} \mathrm{N}$. There is also a similar impact of higher $\mathrm{SO}_{2}$ emissions over $40^{\circ}-70^{\circ} \mathrm{N}$ on Arctic sulphate mixing ratios. This confirms the important role of aerosol and precursor sources in mid- and high latitudes in affecting Arctic aerosol abundance, and suggests that current emissions are likely underestimated, as also shown by Wang et al. (2011).

Our modifications to CAM5 were targeted at improving the simulation of high-latitude and upper-tropospheric aerosols. However, comparison of model-simulated aerosol optical properties to AERONET retrievals and mixing ratios to surface site measurements shows improvements globally and over various regions. Moreover, a number of the modifications led to improvements in the climate simulation such as increases in LWP, which is too low in the standard CAM5. The simulation with the unified convective transport/removal and secondary activation has some of the largest improvements in LWP and cloud forcing compared to the standard and control simulations, and these changes can be attributed to changes in aerosol distributions and resulting feedbacks. These results warrant further exploration into aerosol indirect and semi-direct effects in CAM5 with our new modifications, using the methodology developed by Ghan et al. (2012).

\section{Supplementary material related to this article is available online at: http://www.geosci-model-dev.net/6/ 765/2013/gmd-6-765-2013-supplement.pdf.}

Acknowledgements. This research was supported by the Office of Science of the US Department of Energy (DOE) as part of the Earth System Modeling Program. The Pacific Northwest National Laboratory (PNNL) is operated for DOE by Battelle Memorial Institute under contract DE-AC05-76RLO1830. The CESM project is supported by the National Science Foundation and the DOE Office of Science. The development of the PNNL-MMF was supported by the NASA Interdisciplinary Science Program under grant NNX07AI56G and the DOE Office of Science, Decadal and Regional Climate Prediction using Earth System Models (EaSM) program. We thank D. Koch for providing BC profiles and helpful discussion, J. P. Schwarz for providing the HIPPO BC profiles, and many scientists, engineers and support staff for their efforts in making all the datasets available for our model evaluation. Computational resources were provided by the National Energy Research Scientific Computing Center (NERSC), a national scientific user facility located at Lawrence Berkeley National Laboratory in Berkeley, California. NERSC is the flagship scientific computing facility for the Office of Science in DOE.

Edited by: O. Boucher 


\section{References}

Abdul-Razzak, H. and Ghan, S. J.: A parameterization of aerosol activation 2, Multiple aerosol types, J. Geophys. Res.-Atmos., 105, 6837-6844, 2000.

Adler, R. F., Huffman, G. J., Chang, A., Ferraro, R., Xie, P., Janowiak, J., Rudolf, B., Schneider, U., Curtis, S., Bolvin, D., Gruber, A., Susskind, J., and Arkin, P.: The Version 2 Global Precipitation Climatology Project (GPCP) Monthly Precipitation Analysis (1979-Present), J. Hydrometeor., 4, 1147-1167, 2003.

Albrecht, B.: Aerosols, cloud microphysics, and fractional cloudiness, Science, 245, 1227-1230, 1989.

Bond, T. C., Streets, D. G., Yarber, K. F., Nelson, S. M., Woo, J. H., and Klimont, Z.: A technology-based global inventory of black and organic carbon emissions from combustion, J. Geophys. Res., 109, D14203, doi:10.1029/2003JD003697, 2004.

Boucher, O.: GCM estimate of the indirect aerosol forcing using satellite-retrieved cloud droplet effective radii, J. Climate, 8, 1403-1409, 1995.

Bourgeois, Q. and Bey, I.: Pollution transport efficiency toward the Arctic: Sensitivity to aerosol scavenging and source regions, J. Geophys. Res., 116, D08213, doi:10.1029/2010JD015096, 2011.

Browse, J., Carslaw, K. S., Arnold, S. R., Pringle, K., and Boucher, O.: The scavenging processes controlling the seasonal cycle in Arctic sulphate and black carbon aerosol, Atmos. Chem. Phys., 12, 6775-6798, doi:10.5194/acp-12-6775-2012, 2012.

Collins, W. D., Rasch, P. J., Eaton, B. E., Khattatov, B., Lamarque, J.-F., and Zender, C. S.: Simulating aerosols using a chemical transport model with assimilation of satellite aerosol retrievals: Methodology for INDOEX. J. Geophys. Res., 106, 7313-7336, doi:10.1029/2000JD900507, 2001.

Cozic, J., Verheggen, B., Mertes, S., Connolly, P., Bower, K., Petzold, A., Baltensperger, U., and Weingartner, E.: Scavenging of black carbon in mixed phase clouds at the high alpine site Jungfraujoch, Atmos. Chem. Phys., 7, 1797-1807, doi:10.5194/acp-7-1797-2007, 2007.

Croft, B., Pierce, J. R., Martin, R. V., Hoose, C., and Lohmann, U.: Uncertainty associated with convective wet removal of entrained aerosols in a global climate model, Atmos. Chem. Phys., 12, 10725-10748, doi:10.5194/acp-12-10725-2012, 2012.

Dentener, F., Kinne, S., Bond, T., Boucher, O., Cofala, J., Generoso, S., Ginoux, P., Gong, S., Hoelzemann, J. J., Ito, A., Marelli, L., Penner, J. E., Putaud, J.-P., Textor, C., Schulz, M., van der Werf, G. R., and Wilson, J.: Emissions of primary aerosol and precursor gases in the years 2000 and 1750 prescribed data-sets for AeroCom, Atmos. Chem. Phys., 6, 4321-4344, doi:10.5194/acp-64321-2006, 2006.

Doherty, S. J., Warren, S. G., Grenfell, T. C., Clarke, A. D., and Brandt, R. E.: Light-absorbing impurities in Arctic snow, Atmos. Chem. Phys., 10, 11647-11680, doi:10.5194/acp-1011647-2010, 2010.

Eleftheriadis, K., Vratolis, S., and Nyeki, S.: Aerosol black carbon in the European Arctic: Measurements at Zeppelin station, Ny-Ålesund, Svalbard from 1998-2007, Geophys. Res. Lett., 36, L02809, doi:10.1029/2008GL035741, 2009.

Fan, S.-M., Schwarz, J. P., Liu, J., Fahey, D. W., Ginoux, P., Horowitz, L. W., Levy II, H., Ming, Y., and Spackman, J. R.: Inferring ice formation processes from globalscale black carbon profiles observed in the remote atmosphere and model simulations, J. Geophys. Res., 117, D23205,
doi:10.1029/2012JD018126, 2012.

Feingold, G., Koren, I., Wang, H., Xue, H., and Brewer, W. A.: Precipitation-generated oscillations in open cellular cloud fields, Nature, 466, 849-852, 2010.

Flanner, M. G., Zender, C. S., Randerson, J. T., and Rasch, P. J.: Present-day climate forcing and response from black carbon in snow, J. Geophys. Res.-Atmos., 112, D11202, doi:10.1029/2006jd008003, 2007.

Fridlind, A. M., Ackerman, A. S., Jensen, E. J., Heymsfield, A. J., Poellot, M. R., Stevens, D. E., Wang, D., Miloshevich, L. M., Baumgardner, D., Lawson, R. P., Wilson, J. C., Flagan, R. C., Seinfeld, J. H., Jonsson, H. H., VanReken, T. M., Varutbangkul, V., and Rissman, T. A.: Evidence for the predominance of midtropospheric aerosols as subtropical anvil nuclei, Science, 303, 718-722, 2004.

Garrett, T. J., Brattström, S., Sharma, S., Worthy, D. E. J., and Novelli, P.: The role of scavenging in the seasonal transport of black carbon and sulfate to the Arctic, Geophys. Res. Lett., 38, L16805, doi:10.1029/2011GL048221, 2011.

Gettelman, A., Morrison, H., and Ghan, S. J.: A new twomoment bulk stratiform cloud microphysics scheme in the community atmosphere model, version 3 (CAM3), Part II: Single column and global results, J. Climate, 21, 3660-3679, doi:10.1175/2008jcli2116.1, 2008.

Ghan, S. J., Liu, X., Easter, R. C., Zaveri, R., Rash, P. J., Yoon, J.H., and Eaton, B.: Toward a minimal representation of aerosols in climate models: Comparative decomposition of aerosol direct, semi-direct and indirect radiative forcing, J. Climate, 25, 64616476, doi:10.1175/JCLI-D-11-00650.1, 2012.

Heidam, N. Z., Wåhlin, P., and Christensen, J. H.: Tropospheric gases and aerosols in northeast Greenland. J. Atmos. Sci., 56, 261-278, 1999.

Huang, L., Gong, S. L., Jia, C. Q., and Lavoué, D.: Importance of deposition processes in simulating the seasonality of the Arctic black carbon aerosol, J. Geophys. Res., 115, D17207, doi:10.1029/2009JD013478, 2010.

Kinne, S., Schulz, M., Textor, C., Guibert, S., Balkanski, Y., Bauer, S. E., Berntsen, T., Berglen, T. F., Boucher, O., Chin, M., Collins, W., Dentener, F., Diehl, T., Easter, R., Feichter, J., Fillmore, D., Ghan, S., Ginoux, P., Gong, S., Grini, A., Hendricks, J., Herzog, M., Horowitz, L., Isaksen, I., Iversen, T., Kirkevåg, A., Kloster, S., Koch, D., Kristjansson, J. E., Krol, M., Lauer, A., Lamarque, J. F., Lesins, G., Liu, X., Lohmann, U., Montanaro, V., Myhre, G., Penner, J., Pitari, G., Reddy, S., Seland, O., Stier, P., Takemura, T., and Tie, X.: An AeroCom initial assessment - optical properties in aerosol component modules of global models, Atmos. Chem. Phys., 6, 1815-1834, doi:10.5194/acp-6-1815-2006, 2006.

Koch, D. and Del Genio, A. D.: Black carbon semi-direct effects on cloud cover: review and synthesis, Atmos. Chem. Phys., 10, 7685-7696, doi:10.5194/acp-10-7685-2010, 2010.

Koch, D., Menon, S., Del Genio, A., Ruedy, R., Alienov, I., and Schmidt, G.: Distinguishing aerosol impacts on climate during the past century, J. Climate, 22, 2659-2677, doi:10.1175/2008JCLI2573.1, 2009a.

Koch, D., Schulz, M., Kinne, S., McNaughton, C., Spackman, J. R., Balkanski, Y., Bauer, S., Berntsen, T., Bond, T. C., Boucher, O., Chin, M., Clarke, A., De Luca, N., Dentener, F., Diehl, T., Dubovik, O., Easter, R., Fahey, D. W., Feichter, J., Fillmore, 
D., Freitag, S., Ghan, S., Ginoux, P., Gong, S., Horowitz, L., Iversen, T., Kirkevåg, A., Klimont, Z., Kondo, Y., Krol, M., Liu, X., Miller, R., Montanaro, V., Moteki, N., Myhre, G., Penner, J. E., Perlwitz, J., Pitari, G., Reddy, S., Sahu, L., Sakamoto, H., Schuster, G., Schwarz, J. P., Seland, Ø., Stier, P., Takegawa, N., Takemura, T., Textor, C., van Aardenne, J. A., and Zhao, Y.: Evaluation of black carbon estimations in global aerosol models, Atmos. Chem. Phys., 9, 9001-9026, doi:10.5194/acp-9-9001-2009, 2009b.

Lamarque, J.-F., Bond, T. C., Eyring, V., Granier, C., Heil, A., Klimont, Z., Lee, D., Liousse, C., Mieville, A., Owen, B., Schultz, M. G., Shindell, D., Smith, S. J., Stehfest, E., Van Aardenne, J., Cooper, O. R., Kainuma, M., Mahowald, N., McConnell, J. R., Naik, V., Riahi, K., and van Vuuren, D. P.: Historical (1850-2000) gridded anthropogenic and biomass burning emissions of reactive gases and aerosols: methodology and application, Atmos. Chem. Phys., 10, 7017-7039, doi:10.5194/acp10-7017-2010, 2010.

Law, K. S. and Stohl, A.: Arctic air pollution: Origins and impacts, Science, 315, 1537-1540, doi:10.1126/science.1137695, 2007.

Liu, J., Fan, S., Horowitz, L. W., and Levy, H.: Evaluation of factors controlling long-range transport of black carbon to the Arctic, J. Geophys. Res., 116, D04307, doi:10.1029/2010JD015145, $2011 \mathrm{a}$.

Liu, X., Xie, S., Boyle, J., Klein, S. A., Shi, X., Wang, Z., Lin, W., Ghan, S. J., Earle, M., Liu, P. S. K., and Zelenyuk, A.: Testing cloud microphysics parameterizations in NCAR CAM5 with ISDAC and M-PACE observations. J. Geophys. Res., 116, D00T11, doi:10.1029/2011JD015889, 2011b.

Liu, X., Easter, R. C., Ghan, S. J., Zaveri, R., Rasch, P., Shi, X., Lamarque, J.-F., Gettelman, A., Morrison, H., Vitt, F., Conley, A., Park, S., Neale, R., Hannay, C., Ekman, A. M. L., Hess, P., Mahowald, N., Collins, W., Iacono, M. J., Bretherton, C. S., Flanner, M. G., and Mitchell, D.: Toward a minimal representation of aerosols in climate models: description and evaluation in the Community Atmosphere Model CAM5, Geosci. Model Dev., 5, 709-739, doi:10.5194/gmd-5-709-2012, 2012.

Ma, P.-L., Rasch, P. J., Wang, H., Zhang, K., Easter, R. C., Fast, J. D., Liu, X., Tilmes, S., Yoon, J.-H., and Lamarque, J.-F.: Evaluation of black carbon transport into the Arctic in CAM5: The uncertainty associated with the simulated circulation, J. Geophys. Res., 118, doi:10.1002/jgrd.50411, online first, 2013.

Matsui, H., Kondo, Y., Moteki, N., Takegawa, N., Sahu, L. K., Zhao, Y., Fuelberg, H. E., Sessions, W. R., Diskin, G., Blake, D. R., Wisthaler, A., and Koike, M.: Seasonal variation of the transport of black carbon aerosol from the Asian continent to the Arctic during the ARCTAS aircraft campaign, J. Geophys. Res.-Atmos., 116, D05202, doi:10.1029/2010JD015067, 2011.

McFarquhar, G. M. and Wang, H.: Effects of aerosols on trade wind cumuli over the Indian Ocean: Model simulations, Q. J. R. Meteorol. Soc., 132, 821-843, 2006.

Morrison, H., de Boer, G., Feingold, G., Harrington, J., Shupe, M. D., and Sulia, K.: Resilience of persistent Arctic mixed-phase clouds, Nat. Geosci., 5, 11-17, 2012.

Neale, R. B., Chen, C.-C., Gettelman, A., Lauritzen, P. H., Park, S., Williamson, D. L., Conley, A. J., Garcia, R., Kinnison, D., Lamarque, J.-F., Marsh, D., Mills, M., Smith, A. K., Tilmes, S., Vitt, F., Cameron-Smith, P., Collins, W. D., Iacono, M. J., Easter, R. C., Ghan, S. J., Liu, X., Rasch, P.
J., and Taylor, M. A.: Description of the NCAR Community Atmosphere Model (CAM 5.0), NCAR/TN-486+STR, available at: http://www.cesm.ucar.edu/models/cesm1.0/cam/docs/ description/cam5_desc.pdf (last access: 29 May 2013), 2010.

Pöschl, U., Letzel, T., Schauer, C., and Niessner, R.: Interaction of ozone and water vapor with spark discharge soot aerosol particles coated with benzo[ $\alpha]$ pyrene: $\mathrm{O}_{3}$ and $\mathrm{H}_{2} \mathrm{O}$ adsorption, benzo $[\alpha]$ pyrene degradation, and atmospheric implications, J. Phys. Chem. A, 105, 4029-4041, 2001.

Qian, Y., Flanner, M. G., Leung, L. R., and Wang, W.: Sensitivity studies on the impacts of Tibetan Plateau snowpack pollution on the Asian hydrological cycle and monsoon climate, Atmos. Chem. Phys., 11, 1929-1948, doi:10.5194/acp-11-19292011, 2011.

Qian, Y., Long, C. N., Wang, H., Comstock, J. M., McFarlane, S. A., and Xie, S.: Evaluation of cloud fraction and its radiative effect simulated by IPCC AR4 global models against ARM surface observations, Atmos. Chem. Phys., 12, 17851810, doi:10.5194/acp-12-1785-2012, 2012.

Quinn, P. K., Shaw, G., Andrews, E., Dutton, E. G., RuohoAirola, T., and Gong, S. L.: Arctic haze: Current trends and knowledge gaps, Tellus, Ser. B, 59, 99-114, doi:10.1111/j.16000889.2006.00238.x, 2007.

Riemer, N., Vogel, H., and Vogel, B.: Soot aging time scales in polluted regions during day and night, Atmos. Chem. Phys., 4, 1885-1893, doi:10.5194/acp-4-1885-2004, 2004.

Riemer, N., West, M., Zaveri, R. A., and Easter, R. C.: Simulating the evolution of soot mixing state with a particleresolved aerosol model, J. Geophys. Res.-Atmos., 114, D09202, doi:10.1029/2008jd011073, 2009.

Rosenfeld, D.: Suppression of rain and snow by urban air pollution, Science, 287, 1793-1796, 2000.

Schwarz, J. P., Spackman, J. R., Gao, R. S., Watts, L. A., Stier, P., Schulz, M., Davis, S. M., Wofsy, S. C., and Fahey, D. W.: Global scale black carbon profiles observed in the remote atmosphere and compared to models, Geophys. Res. Lett., 37, L18812, doi:10.1029/2010GL044372, 2010.

Sharma, S., Lavoué, D., Cachier, H., Barrie, L. A., and Gong, S. L.: Long-term trends of the black carbon concentrations in the Canadian Arctic, J. Geophys. Res., 109, D15203, doi:10.1029/2003JD004331, 2004.

Sharma, S., Andrews, E., Barrie, L. A., Ogren, J. A., and Lavoué, D.: Variations and sources of the equivalent black carbon in the high Arctic revealed by long-term observations at Alert and Barrow: 1989-2003, J. Geophys. Res., 111, D14208, doi:10.1029/2005JD006581, 2006.

Shindell, D. T., Chin, M., Dentener, F., Doherty, R. M., Faluvegi, G., Fiore, A. M., Hess, P., Koch, D. M., MacKenzie, I. A., Sanderson, M. G., Schultz, M. G., Schulz, M., Stevenson, D. S., Teich, H., Textor, C., Wild, O., Bergmann, D. J., Bey, I., Bian, H., Cuvelier, C., Duncan, B. N., Folberth, G., Horowitz, L. W., Jonson, J., Kaminski, J. W., Marmer, E., Park, R., Pringle, K. J., Schroeder, S., Szopa, S., Takemura, T., Zeng, G., Keating, T. J., and Zuber, A.: A multi-model assessment of pollution transport to the Arctic, Atmos. Chem. Phys., 8, 5353-5372, doi:10.5194/acp-85353-2008, 2008.

Textor, C., Schulz, M., Guibert, S., Kinne, S., Balkanski, Y., Bauer, S., Berntsen, T., Berglen, T., Boucher, O., Chin, M., Dentener, F., Diehl, T., Easter, R., Feichter, H., Fillmore, D., Ghan, S., Ginoux, 
P., Gong, S., Grini, A., Hendricks, J., Horowitz, L., Huang, P., Isaksen, I., Iversen, I., Kloster, S., Koch, D., Kirkevåg, A., Kristjansson, J. E., Krol, M., Lauer, A., Lamarque, J. F., Liu, X., Montanaro, V., Myhre, G., Penner, J., Pitari, G., Reddy, S., Seland, $\varnothing$., Stier, P., Takemura, T., and Tie, X.: Analysis and quantification of the diversities of aerosol life cycles within AeroCom, Atmos. Chem. Phys., 6, 1777-1813, doi:10.5194/acp-6-1777-2006, 2006.

Textor, C., Schulz, M., Guibert, S., Kinne, S., Balkanski, Y., Bauer, S., Berntsen, T., Berglen, T., Boucher, O., Chin, M., Dentener, F., Diehl, T., Feichter, J., Fillmore, D., Ginoux, P., Gong, S., Grini, A., Hendricks, J., Horowitz, L., Huang, P., Isaksen, I. S. A., Iversen, T., Kloster, S., Koch, D., Kirkevåg, A., Kristjansson, J. E., Krol, M., Lauer, A., Lamarque, J. F., Liu, X., Montanaro, V., Myhre, G., Penner, J. E., Pitari, G., Reddy, M. S., Seland, Ø., Stier, P., Takemura, T., and Tie, X.: The effect of harmonized emissions on aerosol properties in global models an AeroCom experiment, Atmos. Chem. Phys., 7, 4489-4501, doi:10.5194/acp-7-4489-2007, 2007.

Twomey, S.: Pollution and the planetary albedo, Atmos. Environ., 8, 1251-1256, 1974.

Vavrus, S. and Waliser, D.: An Improved Parameterization for Simulating Arctic Cloud Amount in the CCSM3 Climate Model, J. Climate, 21, 5673-5687, doi:10.1175/2008JCLI2299.1, 2008.

Vignati, E., Wilson, J., and Stier, P.: M7: An efficient size- resolved aerosol microphysics module for large-scale aerosol transport models, J. Geophys. Res., 109, D22202, doi:10.1029/2003JD004485, 2004.

Vignati, E., Karl, M., Krol, M., Wilson, J., Stier, P., and Cavalli, F.: Sources of uncertainties in modelling black carbon at the global scale, Atmos. Chem. Phys., 10, 2595-2611, doi:10.5194/acp-102595-2010, 2010.

Wang, H. and Feingold, G.: Modeling mesoscale cellular structures and drizzle in marine stratocumulus, Part I: impact of drizzle on the formation and evolution of open cells, J. Atmos. Sci., 66, 3237-3256, 2009.
Wang, M., Ghan, S., Easter, R., Ovchinnikov, M., Liu, X., Kassianov, E., Qian, Y., Gustafson Jr., W. I., Larson, V. E., Schanen, D. P., Khairoutdinov, M., and Morrison, H.: The multiscale aerosol-climate model PNNL-MMF: model description and evaluation, Geosci. Model Dev., 4, 137-168, doi:10.5194/gmd-4137-2011, 2011a.

Wang, M., Ghan, S., Ovchinnikov, M., Liu, X., Easter, R., Kassianov, E., Qian, Y., and Morrison, H.: Aerosol indirect effects in a multi-scale aerosol-climate model PNNL-MMF, Atmos. Chem. Phys., 11, 5431-5455, doi:10.5194/acp-11-5431-2011, $2011 \mathrm{~b}$.

Wang, M., Ghan, S., Liu, X., L’Ecuyer, T. S., Zhang, K., Morrison, H., Ovchinnikov, M., Easter, R., Marchand, R., Chand, D., Qian, Y., and Penner, J. E.: Constraining cloud lifetime effects of aerosols using A-Train satellite observations, Geophys. Res. Lett., 39, L15709, doi:10.1029/2012GL052204, 2012.

Wang, Q., Jacob, D. J., Fisher, J. A., Mao, J., Leibensperger, E. M., Carouge, C. C., Le Sager, P., Kondo, Y., Jimenez, J. L., Cubison, M. J., and Doherty, S. J.: Sources of carbonaceous aerosols and deposited black carbon in the Arctic in winter-spring: implications for radiative forcing, Atmos. Chem. Phys., 11, 1245312473, doi:10.5194/acp-11-12453-2011, 2011.

Warren, S. G. and Wiscombe, W. J.: A model for the spectral albedo of snow. II: Snow containing atmospheric aerosols, J. Atmos. Sci., 37, 2734-2745, 1980.

Wolff, E. W. and Cachier, H.: Concentrations and seasonal cycle of black carbon in aerosol at a coastal Antarctic station, J. Geophys. Res., 103, 11033-11041, doi:10.1029/97JD01363, 1998.

Zaveri, R. A., Easter, R. C., Barnard, J. C., Riemer, N., and West, M.: Particle-resolved simulation of aerosol size, composition, mixing state, and the associated optical and cloud condensation nuclei activation properties in an evolving urban plume, J. Geophys. Res.-Atmos., 115, D17210, doi:10.1029/2009JD013616, 2010. 